
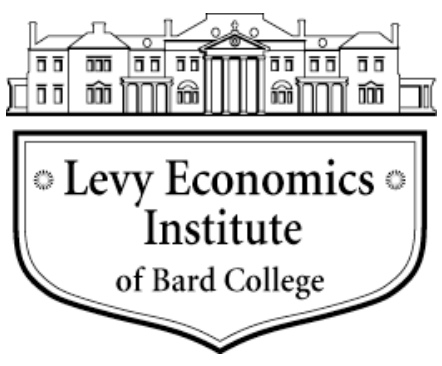

Working Paper No. 733

\title{
Innovation and Finance: An SFC Analysis of Great Surges of Development by
}

\author{
Alessandro Caiani \\ University of Pavia \\ Antoine Godin \\ University of Pavia \\ Stefano Lucarelli \\ University of Bergamo
}

October 2012

The Levy Economics Institute Working Paper Collection presents research in progress by Levy Institute scholars and conference participants. The purpose of the series is to disseminate ideas to and elicit comments from academics and professionals.

Levy Economics Institute of Bard College, founded in 1986, is a nonprofit, nonpartisan, independently funded research organization devoted to public service. Through scholarship and economic research it generates viable, effective public policy responses to important economic problems that profoundly affect the quality of life in the United States and abroad.

\author{
Levy Economics Institute \\ P.O. Box 5000 \\ Annandale-on-Hudson, NY 12504-5000 \\ http://www.levyinstitute.org
}

Copyright (C) Levy Economics Institute 2012 All rights reserved

ISSN 1547-366X 


\begin{abstract}
Schumpeter, a century ago, argued that boom-and-bust cycles are intrinsically related to the functioning of a capitalistic economy. These cycles, inherent to the rise of innovation, are an unavoidable consequence of the way in which markets evolve and assimilate successive technological revolutions. Furthermore, Schumpeter's analysis stressed the fundamental role played by finance in fostering innovation, in defining bank credit as the "monetary complement" of innovation. Nevertheless, we feel that the connection between innovation and firm financing has seldom been examined from a theoretical standpoint, not only by economists in general, but even within the Neo-Schumpeterian research line. Our paper aims at analyzing both the long-term structural change process triggered by innovation and the related financial dynamics inside the coherent framework provided by the stock-flow consistent (SFC) approach. The model presents a multisectoral economy composed of consumption and capital goods industries, a banking sector, and two household sectors: capitalists and wage earners. The SFC approach helps us to track the flows of funds resulting from the rise of innovators in the system. The dynamics of prices, employment, and wealth distribution among the different sectors and social groups is analyzed. Above all, the essential role of finance in fostering innovation and its interaction with the real economy is underlined.
\end{abstract}

Keywords: Schumpeter; Innovation; Stock-flow Consistent Models; Monetary Circuit JEL Classifications: E11, E32, O31 


\section{SCHUMPETERIAN TECHNOLOGICAL CHANGE AND FINANCE}

In most macroeconomic models technological change is introduced as an exogenous stochastic shock that may transiently remove the system from a predetermined steady-state equilibrium path (Castellacci 2008). Hence, these models, at most, may lead to a second best outcome, stemming from an incorrect assessment of some kind of externalities by economic agents leading to a market failure, but not to endogenous instability (Delli Gatti et al. 2010).

Instead, Schumpeter argued that boom and bust cycles are intrinsically related to the functioning of a capitalistic economy (Schumpeter, 1912 [1934], 1939 [1964]). These cycles, inherent to the rise of innovation, are an unavoidable consequence of the way in which the market evolves and assimilates successive technological revolutions. Furthermore, Schumpeter's analysis stressed the fundamental role played by finance in fostering innovation, defining bank credit as the "monetary complement" of innovation. Nevertheless, we feel that the connection between innovation and firm financing has seldom been examined, from a theoretical point of view, not only by economists in general, but even inside the Neo-Schumpeterian research line (O'Sullivan 2000).

The fundamental aim of this paper is to make a contribution toward overcoming this key failing of macroeconomic theory. For this purpose we develop a stock-flow consistent (SFC hereafter) multi-sectorial model in order to analyze medium and long-term business cycles triggered by the emergence of a cluster of innovations. More precisely, we are interested in explaining the dynamics underlying Juglar medium-cycles and Kondratieff long-cycles following Schumpeter's taxonomy. The former are related to credit and how innovation is financed, the latter relate directly to the diffusion process. We chose to focus on the introduction of a bundle of new, more productive, investment goods that are a new kind of capital ${ }^{1}$. Particular attention is given to the interaction between finance and the real economy during each phase of this technology-rooted cycle.

The paper builds the grounds for a wider analysis of the implications of technological progress and structural change processes in a Schumpeterian perspective. This may contribute to the

\footnotetext{
${ }^{1}$ This choice is motivated by two things: first, the focus on a new investment good, instead of a consumer good, gives us an important advantage since it enables us to analyze the process of Schumpeterian competition between the innovative sector and the traditional one on the basis of an objective criterion, represented by the technical coefficients characterizing each technology used in the productive processes. These coefficients directly affect the structure of production costs in each sector. Second, the analysis of economic history shows that the major waves of technological revolution, since the mid-eighteenth century, have focused, at least in the early stages, primarily on capital goods. This observation seems to be confirmed also by the work of Perez $(2002,2009)$ on great surges of development and long waves which identified, for each successive techno-economic paradigm, the technology that can be considered as the most representative.
} 
understanding of the effects on different sectors and groups during the stages of irruption, installation, deployment, and exhaustion of a new techno-economic paradigm (Perez 2010). Contextually, the analysis of financial markets both from the point of view of firms-looking for funding — and from the point of view of investors — seeking remunerative opportunities — may help to identify the potential sources of instability in the context of a financialized monetary economy of production, in particular during periods of radical technological change.

The paper is organized as follows: in this section we discuss the existing literature and describe the methodology, stressing the advantages of using an SFC approach to describe the different monetary circuit characterizing the Schumpeterian process of development. Section 2 contains a description of the model and the behavioral equations of each sector. Section 4 analyzes the results and section 5 concludes.

\subsection{The Innovation-Finance Nexus}

Every time a cluster of radical innovations emerges, it triggers a process of structural change in the economic system. In this phase imbalances usually arise, as the process of structural change sets the stage for the Schumpeterian "creative destruction." New sectors rise, attracting investment due to higher profit opportunities, while the other sectors of the economy experience a deep transformation to adapt to the new economic context or rather, following Perez (2002), to the emerging technoeconomic paradigm.

As the new technologies progressively spread into the economic system, this induces a profound change in the productive and organizational structure of an ever growing number of economic sectors. This in turn usually exerts significant effects in investment behaviors by both non-financial and financial firms, in the labor market, and in the distribution of wealth and income among different social groups, thus affecting the reproduction conditions of the economic system and potentially leading to instability.

Carlota Perez $(2009,2010)$, with her work on technological revolutions and financial capital, is one of the few scholars stressing the relevance of the innovation-finance nexus. She has focused primarily on the role played by financial capital during the "irruption" and "installation" stages of a techno-economic paradigm. Based on historical data her work identified a number of similarities characterizing successive great surges of development. In particular her analysis highlighted the recurrence of "technology rooted bubbles" in the early phase of each great surge of development, explaining it as a consequence of the way a capitalistic economy assimilates a technological revolution. This research line in turn has contributed to stimulate an already going stream of 
empirical studies that have contributed to identify, on a micro level, important stylized facts concerning the innovation-finance nexus (see for example Mazzucato and Tancioni 2010; Mina et al. 2011; Bottazzi et al. 2008), for an extended review of the empirical literature in this field see Lazonick et al. (2010). In particular they have demonstrated that firms' financial structure is likely to affect their investment policies ${ }^{2}$. Furthermore some of these studies (Brown et al. 2009) suggest that young innovative firms today, when seeking external equity, rely more and more on financial markets rather than on bank credit. This would mean that the selection role played by bankers in Schumpeter's original theory of development has been partially delegated to financial markets. The potential implications of this fact are obviously not trivial in light of the peculiar logic characterizing the functioning of financial markets and the recurrence of speculative behaviors. In addition, a number of studies (Mazzucato 2003; Pastor and Veronesi 2009, among others) have shown that stock price volatility increases during the early stage of a new innovative sector and during a period of radical technological change.

The previous arguments seem to confirm the topicality and relevance of Schumpeter's analysis, focusing on the complex feed-backs between innovation and financial dynamics, in the current economic context. Furthermore, the results of these studies clearly ask for a coherent macroeconomic framework suitable for analyzing the interaction between innovation and finance. The elaboration of such a new perspective today is made even more urgent by the new, more significant, and more pervasive role that financial markets play in the functioning of our economic systems, as a consequence of the process of financialization begun more than 30 years ago. Nevertheless, such a framework is still missing.

\subsection{A Tale of Circuits and Matrices}

The stock flow consistent (SFC) approach appears the most suitable to describe the process of development triggered by innovation in a "monetary theory of production" framework, such as the

\footnotetext{
${ }^{2}$ Indeed, since Fazzari et al. (1988), empirical evidence has been growing against the Modigliani and Miller (1958) theorem which predicts that at the margin alternative sources of finance should be perfect substitutes. On the contrary, this huge stream of empirical research has provided solid arguments in favor of a pecking order theory of finance (Meyers 1984) whereby borrowers follow an order of preferences for finance. In the presence of imperfections in capital markets (e.g. information asymmetries), the cost of external finance (both equity and loans) is usually high. These higher costs affect, in particular, young and innovative firms, due to the lack of collateral and the unavoidable difficulties in evaluating ex-ante their future profitability potential. So firms rely first of all on their retained earnings to finance their investment projects, and resort to external financing only after they have exhausted their internal resources.
} 
one presented in Schumpeter's own theory of money ${ }^{3}$. The use of a multi-sectorial SFC model helps to analyze the effect of innovation on different sectors and social groups, during each phase of the technological cycle. One of the fundamental aims of the present work is indeed to make a contribution toward building a new and coherent framework to analyze in a unifying perspective, both the "real" structural change process triggered by innovation and the related "financial" dynamics, thus contributing to our understanding of the pervasive effects generated by innovation and technological change. Each phase of the Schumpeterian process of cyclical development can be represented as a different monetary circuit (Graziani 2003). Indeed, theorists of the monetary circuit are very close to Schumpeter's theory of money, but they have not yet proposed an analytical framework able to clarify the meaning of credit creation when seen as the monetary complement of innovation. The monetary circuit, as some scholars have demonstrated in the last decade (Lavoie 2004; Zezza 2004; Accoce and Mouakil 2005, among others), may be formalized by using the SFC framework.

The SFC approach is based on the seminal works of Wynne Godley and James Tobin ${ }^{4}$ These models are consistent in that every monetary flow in the model is recorded as a payment coming from a sector and a receipt for another sector, following a double-entry accounting approach. Thus in each period, the sum of flows has to be nil. Every flow then affects end-of-period stock values. Stocks are thus the sum of inflows and outflows across time. In turn, stocks may generate flows (such as interest payment on a stock of loans). Stocks, in accordance with the double-entry bookkeeping logic are always recorded as an asset for a sector and a liability for other sectors, their sum thus being nil, too ${ }^{5}$.

The adoption of an SFC methodology thus eliminates black boxes explaining the linkages between stocks and flows and real and nominal variables, acting in this respect as a "conservation of energy principle" for economic theory. This makes SFC models particularly suitable to

\footnotetext{
${ }^{3}$ We refer to "monetary theory of production" as the line of research that, in contrast with neo-classical economics, supports the thesis of money non-neutrality, whereas we use the notion of "monetary circuit" to intend a single production period in a pure credit economy with no government.

${ }^{4}$ See Dos Santos (2006) for a historical review of the emergence of SFC, and Godley and Lavoie (2007) for extensive examples of SFC models.

${ }^{5}$ Notice that the SFC approach follows exactly the same logic used by the UN System of National Account (SNA). The actual SNA was first presented in 1968 to answer the concerns of economists like Copeland and Denizet who had been complaining about the lack of integration between the flows of the real economy and its financial side, affecting the National Systems accounting rules. The new system provided a theoretical scheme that stressed the integration of the national income accounts with financial transactions, capital stocks, and balance sheet (as well as input-output accounts) Godley and Lavoie (2007). The construction of the Transaction Flow Matrixes, used in SFC models to record the flows of funds and their impact on stock, thus totally resembles that of the National Income and Product Account Matrix (NIPA). Similarly the SFC models balance sheets, representing how stock is distributed among sectors, perfectly resembling the balance sheets of the SNA.
} 
theoretical frameworks based on endogenous money. Since they link real and nominal variables they help track the flows of funds resulting from a cluster of innovations in the system and their impact on stocks. For this reason, they appear especially adequate to analyze the interdependencies between technological change—affecting labor and capital productivity—and its finance. In particular, the adoption of a multi-sectorial SFC approach may significantly contribute to improving our understanding of the dynamics of prices ${ }^{6}$, wages, profits, employment, and wealth distribution among the various sectors and social groups characterizing our economy, and across the different phases of the process of structural change triggered by innovation.

\subsection{Banks, Financial Markets, and Innovation}

Figure 1 depicts the flow diagram of the economy at hand. We have two household sectors: wage earners and capitalists. Wage earners offer labor in exchange for a wage and capitalists own the firms through shares and receive dividends from firms and from banks. Both sectors are saving part of their income and thus build a stock of financial wealth. While wage earners' savings are held as cash, capitalists distribute their financial wealth among four assets, money and three types of shares issued by each productive sector, their portfolio choice being based on a comparison between each asset's expected return rate. All productive sectors need capital to produce their own good.

Consumption good firms invest either in traditional or in innovative capital goods, their choice being based on their relative costs, (depending on the price and productivity of each capital).

Traditional capital firms produce their output using only traditional capital. Innovative capital good producers instead first produce with the traditional capital $\operatorname{good}^{7}$, while in the successive periods, similar to the traditional capital good sector, they produce their output only with innovative capital goods.

Each industry has three separate sources of finance: retained earnings, emission of equities (new issues of shares), and bank credit. This implies that firms decide not only how much to invest but also how to finance their investment. Their financing decision is based on the pecking order theory of finance privileging internal resources. The choice between the two kinds of external finance (a residual when internal resources are not enough) is based on their relative costs. On the

\footnotetext{
${ }^{6}$ Of both real good and financial assets.

${ }^{7}$ Schumpeter in fact stressed that each entrepreneur has to master the organization of the new productive process, before being able to supply the final goods. He argued that "the carrying into effect of an innovation involves, not primarily an increase in existing factors of production, but the shifting of existing factors from old to new uses" (Schumpeter 1964/1939, p.110) and that the entrepreneur "withdraws, by his bids for producers' goods, the quantities of them he needs from the uses which they served before" (Schumpeter 1964/1939, p.133). Production of the innovative good thus takes time to come into effect. Hence the first effect of the appearance of entrepreneurial demand should be an increase in the demand for traditional capital goods.
} 
other hand, banks discriminate between different producers by applying different rates of interest, on the basis of the perceived risk related to each loan granted.

Finally, investors base their portfolio choices on expectations formed by looking at past performance, in terms of dividends, capital gains, and profits, of the different types of securities. In this way, the model aims at providing an explanation of technological rooted business cycle that explicitly takes into account the interaction between real and financial side of the economy. The adoption of a SFC framework is a key aspect in this respect since it avoids black boxes between real and nominal variables. Table 3 in appendix A, shows the transaction flow matrix of the economy. A list of all variables and their signification may be found in appendix B.

\section{SECTORIAL BEHAVIORS}

As already mentioned, there are five different sectors in our economy: a household sector, three productive sectors, and a banking sector.

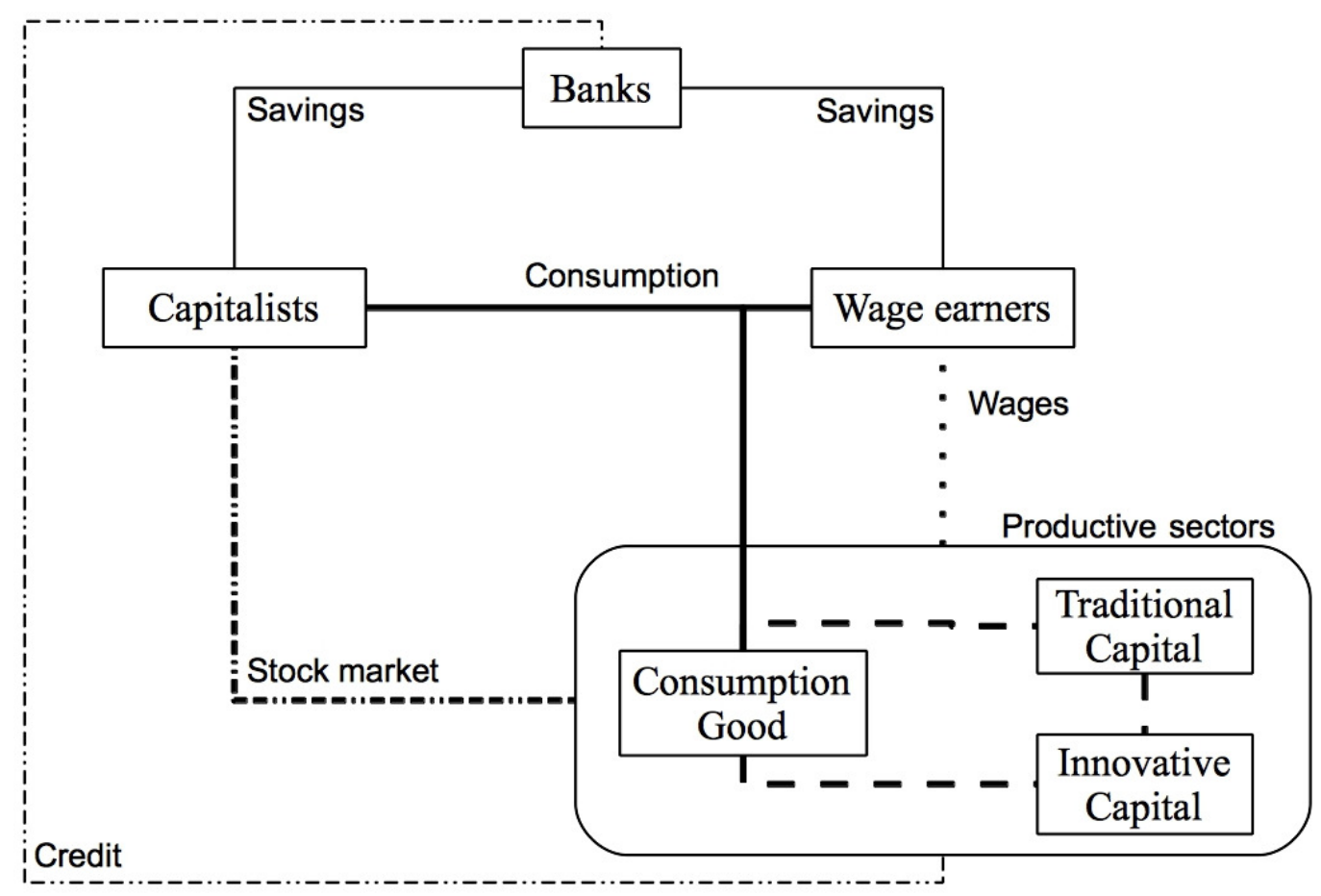

Figure 1: Flow diagram of the model. Both household sectors consume (thick solid line) goods from the consumption good industry. Wage earners obtain wages (dotted line) in exchange for labor from all productive sectors and save (thin solid line) what is not consumed. Capitalists obtain dividends from the equities they hold (thick dash-dotted line) and store as cash (thin solid line) the remaining of their wealth. Banks store deposits from both sector households 
and grant credit (thin dash-dotted line) to all three productive sectors. Finally, all productive sectors need capital, traditional or innovative, to produce their own goods (thick dashed line).

\subsection{Households}

In each period, all households, capitalists or wage earners, decide how much to consume. Real consumption level is a function of expected real disposable income and previous period real wealth (2.1). We adopt backward looking expectations (2.3). Expected real disposable income, defined à la Haig-Simons ${ }^{8}$, is equal to real expected income minus the inflationary impact on wealth (2.2). Nominal consumption is then computed using consumption goods price. All nominal income that is not spent is saved (2.4).

$$
\begin{aligned}
& c=\alpha_{1} \cdot y d^{e}+\alpha_{2} \cdot v_{-1} \\
& y d^{e}=\frac{Y D^{e}}{p_{c}}-\pi_{c} \frac{V_{-1}}{p_{c}} \\
& Y D^{e}=\sum_{i=1}^{4} \frac{1}{4} Y D_{t-i} \\
& \Delta V=Y D-C
\end{aligned}
$$

\subsubsection{Wage Earners}

Wage earner's nominal income is composed of wage received from all industries (2.5). Wage earners save all their wealth as cash (2.6).

$$
\begin{aligned}
& Y D_{w}=W_{c} N_{c}+W_{k} N_{k}+W_{i} N_{i} \\
& M_{w}=V_{w}
\end{aligned}
$$

\subsubsection{Capitalists}

Capitalists' personal income is composed of dividends from all industries as well as from banks (2.7). Capitalists' disposable income is composed of their personal income and capital gains (2.8).

$$
\begin{aligned}
& Y P_{c}=F D_{c}+F D_{k}+F D_{i}+F D_{b} \\
& Y D_{c}=Y P_{c}+C G \\
& C G=\sum_{j \in c, k, i} e_{j,-1} \Delta p_{j, e}
\end{aligned}
$$

\footnotetext{
${ }^{8}$ Haig (1921) and Simons (1938) define income as the sum of consumption and variation in wealth. According to Godley and Lavoie (2007, pp. 293-294), Haig-Simons' real disposable income is composed of real disposable income minus the loss of real wealth due to inflation.
} 
Capitalists' wealth $V_{c}$ is formed by the sum of cash $M_{c}$ and the part of financial wealth held as equities $V_{e c}=e_{c} p_{c, e}+e_{k} p_{k, e}+e_{i} p_{i, e}$ (2.10). We assume that capitalists hold cash for two reasons: consumption and as a store of wealth. We thus have two equations describing cash demand. The first one expresses cash holding as a fraction of consumption (2.11), the second one is embedded in the portfolio decision, which will be described hereafter.

$$
\begin{aligned}
& V_{c}=M_{c}^{h}+V_{e c} \\
& M_{c}^{d, c}=\beta_{c} C_{c}
\end{aligned}
$$

We assume cash to be the equalizing buffer stock. Following Foley (1975) and many SFC authors, the level of financial assets held might not be equal to their desired level. We thus need one asset, which will absorb the difference between aggregate level and aggregate desired level. In our model, cash is that buffer stock asset. (2.12) and (2.13) describe how expected wealth stocks are computed. The portfolio choice is then made, based on the expected level of financial wealth $V_{f c}^{e}$. Because we assume that cash holding is the buffer stock, we have that expected financial wealth is always equal to held financial wealth $V_{f c}^{e}=V_{f c}$. However, total wealth at the end of the period might not be equal to expected total wealth, we thus have that cash holding $\left(M_{c}^{h}, 2.10 . \mathrm{A}\right)$ might not be equal to its desired level $\left(M_{c}^{d}, 2.16\right)$.

$$
\begin{aligned}
& V_{c}^{e}=V_{c,-1}+Y D_{c}^{e}-C_{c} \\
& V_{f c}^{e}=V_{c}^{e}-M_{c}^{d, c} \\
& V_{f c}=V_{e c}+M_{c}^{d, f} \\
& V_{c}=V_{c,-1}+Y D_{c}-C_{c} \\
& M_{c}^{d}=M_{c}^{d, c}+M_{c}^{d, f} \\
& M_{c}^{h}=V_{c}-V_{e c}
\end{aligned}
$$

Capitalists have to make a portfolio choice in each period. We follow a Tobinesque approach of portfolio choice (Brainard and Tobin 1968) ${ }^{9}$. Nominal holding in equities and cash

\footnotetext{
${ }^{9}$ However, diverging from most SFC authors, we allow for the $\lambda_{x 0}$ to be endogenously determined through size, measured as nominal full capacity output, of each industry. This is due to the fact than in other SFC models, the dimensions of each industry are relatively stable and thus these authors are interested in the impacts of return rates on the portfolio distribution. However, in our case we have to take into account the varying size of each sector, having one sector which rises from zero while another disappears.
} 
depends on the expected real return rate on each asset (2.17\}) to (2.20). We assume that the expected real return rate is based on a weighted sum of expectations on real relative capital gains $\left(c g_{x}^{e}, 2.25\right)$, real relative dividend rate $\left(r^{e}, 2.26\right)$ and real relative profit rate $\left(r g^{e}, 2.27\right)$. The supply of equities being determined by firms, prices are such that the market clears.

$$
\begin{aligned}
& R R_{m}=\frac{-\pi_{c}}{1+\pi_{c}} \quad(2.17) \\
& R R_{c}=\zeta_{1}\left(\frac{1+c g_{c}^{e}}{1+\pi_{c}}-1\right)+\zeta_{2}\left(\frac{1+r_{c}^{e}}{1+\pi_{c}}-1\right)+\zeta_{3}\left(\frac{1+r g_{c}^{e}}{1+\pi_{c}}-1\right) \\
& R R_{k}=\zeta_{1}\left(\frac{1+c g_{k}^{e}}{1+\pi_{c}}-1\right)+\zeta_{2}\left(\frac{1+r_{k}^{e}}{1+\pi_{c}}-1\right)+\zeta_{3}\left(\frac{1+r g_{k}^{e}}{1+\pi_{c}}-1\right) \\
& R R_{i}=\zeta_{1}\left(\frac{1+c g_{i}^{e}}{1+\pi_{c}}-1\right)+\zeta_{2}\left(\frac{1+r_{i}^{e}}{1+\pi_{c}}-1\right)+\zeta_{3}\left(\frac{1+r g_{i}^{e}}{1+\pi_{c}}-1\right) \\
& M_{c}^{d, f}=\left(\lambda_{10}+\lambda_{11} R R_{m}+\lambda_{12} R R_{c}+\lambda_{13} R R_{k}+\lambda_{14} R R_{i}\right) V_{f c}^{e} \\
& e_{c} p_{c, e}=\left(\lambda_{20}+\lambda_{21} R R_{m}+\lambda_{22} R R_{c}+\lambda_{23} R R_{k}+\lambda_{24} R R_{i}\right) V_{f c}^{e} \\
& e_{k} p_{k, e}=\left(\lambda_{30}+\lambda_{31} R R_{m}+\lambda_{32} R R_{c}+\lambda_{33} R R_{k}+\lambda_{34} R R_{i}\right) V_{f c}^{e} \\
& e_{i} p_{i, e}=\left(\lambda_{40}+\lambda_{41} R R_{m}+\lambda_{42} R R_{c}+\lambda_{43} R R_{k}+\lambda_{44} R R_{i}\right) V_{f c}^{e}
\end{aligned}
$$

Expectation are based on the last 4 periods:

$$
\begin{aligned}
& c g^{e}=\frac{C G^{e}}{e_{-1} p_{e,-1}} \\
& r^{e}=\frac{F D^{e}}{e_{-1} p_{e,-1}} \\
& r g^{e}=\frac{F^{e}}{e_{-1} p_{e,-1}} \\
& C G^{e}=\sum_{i=1}^{4} \frac{1}{4} C G_{-i}, F D^{e}=\sum_{i=1}^{4} \frac{1}{4} F D_{-i}, F^{e}=\sum_{i=1}^{4} \frac{1}{4} F_{-i}
\end{aligned}
$$

\subsection{Productive Sectors}

Before analysing each sector peculiarities, we observe general behaviors, common to all productive sectors. 


\subsubsection{Technology}

Technology is fully described by three characteristics:

1. $p r_{k}=\frac{y}{k}$, the average capital productivity, that is the output to capital ratio

2. $p r_{N}=\frac{y}{N}$, the average labor productivity or the output to labor ratio

3. $l_{T}=\frac{k}{N}$, the capital-labor ratio.

However all three characteristics are interrelated, $p r_{N}=p r_{k} l_{T}$, and we may thus use the couple $\left\{p r_{k}, l_{T}\right\}$ to define a technology.

Our model thus describes an economy in which, at a certain point, an innovative capital good is introduced in the capital good market. Once the innovative good is produced and sold, there are two different capital goods (traditional and innovative) and three different productive sectors (consumption, capital, and innovative). Each combination of the couple capital good-sector thus defines a particular technology of production represented by the couple $\left\{p r_{y x}, l_{y x}\right\}$, where $p r_{y x}$ is the productivity of type $x$ capital and $l_{y x}$ is the labor/capital ratio requested by capital good $x$ when employed in sector $y$. Table 1 describes the different technologies at hand. For simplicity reasons we assume that the productivity of each investment good and their capital-labor ratio are the same across sectors (that is $p r_{c k}=p r_{k k}=p r_{i k}=p r_{k}, \quad l_{c, k}=l_{k, k}=l_{i, k}=l_{k} \quad$ and $\quad p r_{c i}=p r_{i i}=p r_{i}$, $\left.l_{c, i}=l_{i, i}=l_{i}\right)^{10}$. The new investment good has a higher productivity of capital $p r_{i}>p r_{k}$ and we further assume that the capital-labor ratio of the two types of capital is the same: $l_{k}=l_{i}$. Notice that this implies that the productivity of labor is higher when using the innovative good.

\footnotetext{
${ }^{10}$ These assumptions however, do not affect, in any significant way, the qualitative results of the model.
} 


\begin{tabular}{|l|c|c|}
\hline Sector Capital good & Traditional & Innovative \\
\hline Consumption & $p r_{k}, l_{k}$ & $p r_{i}, l_{i}$ \\
\hline Capital & $p r_{k}, l_{k}$ & $p r_{i}, l_{i}$ \\
\hline Innovative & $p r_{k}, l_{i k}$ & $p r_{i}, l_{i}$ \\
\hline
\end{tabular}

\section{Table 1: Technology Characterization According to Sector and Capital Good Used}

\subsubsection{Wages and Unit Costs}

Each industry's nominal wage is a function of its previous period targeted and realized real wage (2.29). Targeted real wage depends on that sector's labor productivity $\overline{p r_{x}}$ and $\frac{N}{L F}$, the aggregate employment rate (2.30). Productivity in each sector is determined by an average of the capital stock productivity (2.31.A). However, for simplicity, we assume that workers are not able to observe the utilization rates and use (2.31.B) as an approximation.

$$
\begin{aligned}
W & =W_{-1}+\Omega_{3}\left(\omega_{-1}^{T}-\frac{W_{-1}}{p_{c,-1}}\right) \\
\omega^{T} & =\Omega_{0}+\Omega_{1} \log \left(\overline{p r_{x}}\right)+\Omega_{2} \log \left(\frac{N}{L F}\right) \\
\overline{p r_{x}} & =p r_{k} l_{k} \frac{N_{x, k}}{N_{x}}+p r_{i} l_{i} \frac{N_{x, i}}{N_{x}} \\
& =p r_{k} u_{k, x} \frac{k_{x}}{N_{x}}+p r_{i} u_{i, x} \frac{i_{x}}{N_{x}} \\
& \cong p r_{k} \frac{k_{x}}{N_{x}}+p r_{i} \frac{i_{x}}{N_{x}}
\end{aligned}
$$

Since there are no inputs other than labor, unit costs are defined as the wage bill divided by real output. If only one kind of capital is used to produce, then unit costs reduce to (2.32).

$U C=\frac{W N}{y}=\frac{W \frac{y}{p r . l}}{y}=\frac{W}{p r . l}$

However, in the case of the consumption good industry or of the innovative firm, two kinds of capital are used: traditional and innovative. Hence, unit costs are based on the quantity of innovative and traditional capital goods used. Because innovative capital is more productive, it is 
reasonable to assume that firms chose first to produce using innovative goods and then, using traditional goods ${ }^{11}$. We thus face a non-constant unit cost function depending on total output produced. If demand in consumption good $y$ is lower than the maximum level of output produced by innovative goods $\left(y_{f c, i}, 2.33\right)$, then, since only one source of capital is used, (2.32) is valid. However, if $y>y_{f c, i}$, both capitals are used and unit costs depends on wages, employment, and output. Total output is produced using both capitals following (2.34) where $u_{x, k}$ is the utilization rate of traditional capital in the given sector (2.35). Employment is determined through the capitallabor ratio of each type of capital multiplied by their respective utilization rates (2.36). Unit costs, in this case take the form (2.32.A), which can be simplified to (2.32.B) using the assumption $l_{k}=l_{i}$.

$$
\begin{aligned}
& y_{f c, i}=i . p r_{i} \\
& y=i . p r_{i}+u_{x, k} k \cdot p r_{k} \\
& u_{x, k}=\frac{y-y_{f c, i}}{k \cdot p r_{k}} \\
& N=\frac{i}{l_{i}}+u_{x, k} \frac{k}{l_{k}} \\
& U C=W \frac{i . l_{k}+u_{x, k} k \cdot l_{i}}{\left(i . p r_{i}+u_{x, c} k \cdot p r_{k}\right) l_{i} l_{k}} \\
& =W \frac{y+i\left(p r_{k}-p r_{i}\right)}{l_{k} p r_{k} y}
\end{aligned}
$$

The unit cost function in the consumption good production industry is thus given by (2.37). Figure 2 represents such a unit cost function.

$$
U C(y)= \begin{cases}\frac{W}{p r_{i} l_{i}} & \text { if } y \leq y_{f c i} \\ W \frac{y+i\left(p r_{k}-p r_{i}\right)}{l_{k} p r_{k} y} & \text { if } y>y_{f c i}\end{cases}
$$

\footnotetext{
${ }^{11}$ In this paper, we follow Robinson (1969) in that firms might make mistakes in their estimation of output growth creating unwanted excess capacity; and Lavoie (1992) as firms also plan some excess capacity in order to avoid constraining demand in case of large growth in demand. Firms maintain an excess of total production capacity and not an excess of capacity per type of capital.
} 


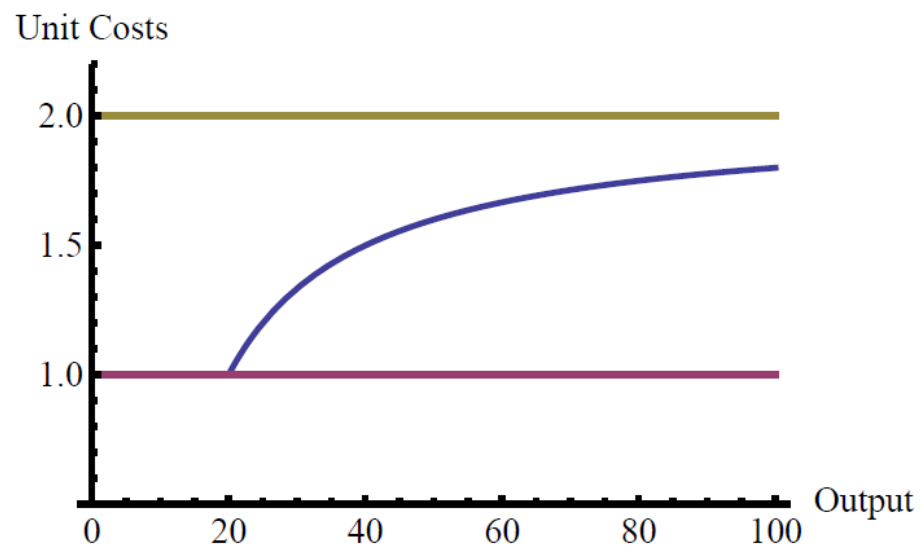

Figure 2: Piecewise unit cost function in the consumption good production industry. Unit costs are constant at the innovative unit costs (in this case 1.0) up to full capacity utilization of innovative capital (output $=\mathbf{2 0}$ ) and then are an increasing function of output, tending towards the traditional unit costs $(\mathbf{2 . 0})$. The more innovative capital the consumption good producer owns, the larger is the quantity of output produced at innovative unit costs.

\subsubsection{Pricing Decision and Investment}

Prices are kaleckian mark-up on unit costs (2.38). Following Lavoie (1992), the mark-up $\left(\phi_{x}, 2.39\right)$ is endogenously determined through $r_{x}$, the desired return on capital in sector $x$, and expected output and expected unit costs, $y_{x}^{e}$ and $U C_{x}\left(y_{x}^{e}\right)$ respectively. Expected output growth is inversely proportional to price inflation (2.40), whereas firms expect their demand to decrease when the price of their output increases.

$p_{x}=\left(1+\phi_{x}\right) U C_{x}\left(y_{x}^{e}\right)$

$\phi_{x}=\frac{r_{x}\left(p_{k,-1} k_{x,-1}+p_{i,-1} i_{x,-1}\right)}{U C_{x}\left(y_{x}^{e}\right) y_{x}^{e}}$

$y_{x}^{e}=y_{x,-1}\left(1-\pi_{x}\right)$

Instead of defining the usual capital stock growth function, we define a practical full capacity $^{12}$ growth function. Indeed, while it is easy to define a capital stock growth function when only one type of capital exists, it is more convenient to define a maximum output growth function in the case of multiple sorts of capital. This full capacity growth function reduces to a capital stock growth function for both capital good sectors since they only use one type of capital. We will

\footnotetext{
${ }^{12}$ Practical or engineer-rated full capacity is the maximum level of production such that it allows normal maintenance and renovation of machinery to take place without impeding production (Eichner1976; Steind11952).
} 
analyze the growth function and leave the details of how capital stock adjusts for each sector's description. Output growth is a function ${ }^{13}$ of expected capacity utilization $u^{e}$, real interest rates $r r_{l}$, leverage level $\lambda$ and Tobin's $q$ (2.41). Expected capacity utilization (2.42) is defined as the ratio of expected output $(y)$ and practical full capacity output. Tobins' $q$ is defined here as the ratio between the market value of the firms and its net worth (2.44).

$$
\begin{aligned}
g_{y} & =\eta_{0}+\eta_{1} u^{e}-\eta_{2} r r_{l} \lambda_{-1}+\eta_{3} q_{-1} \\
u^{e} & =\frac{y^{e}}{k_{-1} \cdot p r_{k}+i_{-1} \cdot p r_{i}} \\
\lambda & =\frac{L}{k \cdot p_{k}+i \cdot p_{i}} \\
q & =\frac{e \cdot p_{e}}{k \cdot p_{k}+i \cdot p_{i}}
\end{aligned}
$$

\subsubsection{Financing Decision}

As already explained, firms have three sources of funds to finance investments: profits, equities emissions, and bank credit. We assume that firms always first use their profits net of interests $F=Y-W N-r_{l,-1} L_{-1}$ to finance investment $I$. If profits are larger than investments, the remaining part of profits is distributed as dividend, $F D=F-I$. If the need for finance is larger than profits, firms then have to decide how to finance the remaining part $I_{f}=I-F$. We assume that the share $\Psi$ of investments funded by equities emission is a function of the capital gains, relative to the firm's market value, $(c g, 2.46)$ and $r_{l}$, the interest rate on loans $(2.45)$. The quantities of equities emitted, $e^{s}$, depends on $p_{e,-1}$, the price of equities in the previous period (2.47). The quantities of equities on the market are thus equal to their previous period number plus new emissions (2.48). Finally, loans are the residual between need for finance and the quantity of funds raised by equities emission, which depends on the realized market price for equities (2.49).

$$
\Psi_{c}=\frac{1}{1+\exp \left[\psi\left(r^{T}-c g_{-1}-r_{l}\right)\right]}
$$

\footnotetext{
${ }^{13}$ We use here a simplified version of Fazzari and Mott (1987), and Lavoie and Godley (2002), since we assume that firms have fixed return rates. The effect of this normally non-fixed variable is thus contained in $\eta_{0}$.
} 


$$
\begin{aligned}
& c g=\frac{C G}{p_{e,-1} e_{-1}} \\
& e^{s}=\frac{\Psi I_{f}}{p_{e,-1}} \\
& e=e_{-1}+e^{s} \\
& \Delta L=I_{f}-e^{s} p_{e}
\end{aligned}
$$

\subsubsection{Consumption Good Sector}

Real demand in consumption goods is determined by the consumption decision of both household sectors $y_{c}=c_{c}+c_{w}$. Consumption good industry follows the pricing and investment decisions described in section 2.2.3. However, the real interest rate in the case of the consumption good sector is particular. Indeed, real interest rate is defined as the nominal interest rate deflated by capital price inflation. However in our case, there are two prices for capital, we have thus defined a capital price inflation based on consumption good industry's stock of both capital and their relative price inflation (2.51).

$$
\begin{aligned}
& r r_{l c}=\frac{1+r_{l}}{1+\overline{\pi_{k, i}}}-1 \\
& \overline{\pi_{k, i}}=\frac{k_{c,-1} \pi_{k}+i_{c,-1} \pi_{i}}{k_{c,-1}+i_{c,-1}}
\end{aligned}
$$

As mentioned earlier, consumption good producers use both kinds of capital and thus may choose to invest in any of this type of capital. Given the desired growth in productive capacity, they have to choose in which kind of capital to invest. We assume they do so based on the relative cost of the two kinds of capital (2.54). Because their demand in the desired type of capital might be frustrated, we take into account this situation (2.55)-(2.61) where $i_{s}$ and $k_{s}$ are the quantity of innovative and traditional goods available. The investment decision is thus a two-step process: first capital producers announce their price and the quantity of goods available, then the consumption good producers decide how much to invest based on their capacity utilization rate and the real interest rate they face and in which good to invest based on relative costs and availability of goods. The finance of this desired investment in capital follows the rule determined in section 2.2.4 and is not repeated here. 


$$
\begin{aligned}
& g_{y c}=\eta_{c, 0}+\eta_{c, 1} u_{c}^{e}-\eta_{c, 2} r r_{l, c} \lambda_{c,-1}+\eta_{c, 3} q_{c,-1} \\
& i n v_{y, c}=g_{y c} y_{c,-1}+d\left(k_{c}\right) p r_{k}+d\left(i_{c}\right) p r_{i} \\
& \cos t_{k}=\frac{p_{k}}{p r_{k}}, \quad \cos t_{i}=\frac{p_{i}}{p r_{i}} \\
& i_{c, i}=z_{1}\left[z_{2} i_{s}+\left(1-z_{2}\right) \frac{i n v_{y, c}}{p r_{i}}\right]+\left(1-z_{1}\right) z_{3}\left[z_{4} i_{s}+\left(1-z_{4}\right) \frac{i n v_{y, c}-k_{s} p r_{k}}{p r_{i}}\right] \\
& i_{c, k}=z_{1} z_{2}\left[z_{5} k_{s}+\left(1-z_{5}\right) \frac{i n v_{y, c}-i_{s} p r_{i}}{p r_{k}}\right]+\left(1-z_{1}\right)\left[z_{3} k_{s}+\left(1-z_{3}\right) \frac{i n v_{y, c}}{p r_{k}}\right] \\
& z_{1}=1 \text { if } \cos t_{k}>\cos t_{i}, \quad 0 \text { otherwise } \\
& z_{2}=1 \quad \text { if } \quad \frac{i n v_{y, c}}{p r_{i}}>i_{s}, \quad 0 \text { otherwise } \\
& z_{3}=1 \text { if } \frac{i n v_{y, c}}{p r_{k}}>k_{s}, \quad 0 \text { otherwise } \\
& z_{4}=1 \quad \text { if } \quad \frac{i n v_{y, c}-k_{s} p r_{k}}{p r_{i}}>i_{s}, \quad 0 \text { otherwise } \\
& z_{5}=1 \text { if } \frac{i n v_{y, c}-i_{s} p r_{i}}{p r_{k}}>k_{s}, \quad 0 \text { otherwise }
\end{aligned}
$$

\subsubsection{Traditional Capital Good Industry}

The traditional capital good industry faces a demand depending on the investment decisions by the three productive sectors $y_{k}=i_{c, k}+i_{k, k}+i_{i, k}^{14}$. They follow the pricing, investment, and financing rules defined in section 2.2.3 and 2.2.4. However, it is interesting to note that since traditional capital good producers only use one kind of capital, they face constant unit costs (2.62). Investment reduces to (2.64) as traditional capital producers only invest in traditional capital.

$$
\begin{aligned}
& U C_{k}=\frac{W}{p r_{k} l_{k}} \\
& g_{y k}=\eta_{k, 0}+\eta_{k, 1} u_{k}^{e}-\eta_{k, 2} r r_{l, k} \lambda_{k,-1}+\eta_{k, 3} q_{k,-1}
\end{aligned}
$$

\footnotetext{
${ }^{14}$ The innovative firm will invest in traditional goods only in the first sub-phase, i.e. when they need capital to produce their first batch of the innovative capital good. See section 2.2.7 for more information.
} 


$$
i_{k, k}=d\left(k_{k}\right)+\frac{g_{y k}}{p r_{k}}
$$

\subsubsection{Innovative Capital Good Industry}

Before entering the capital good market, an innovative firm must produce their first batch of capital good. In order to produce it, they need to buy traditional capital goods. We assume that firms and banks determine the quantity of credit needed in order to have enough capital good so that when entering the market, they attain a certain market share $\psi$ as well as a growth rate of potential output $\tau$. The parameters $\psi$ and $\tau$ might be seen as the result of a bargain between bankers and innovators, ensuring that the firm will make profits soon enough to be able to repay part of their loans. The system of equations determining the credit $L_{i}$ is the following:

$$
\begin{aligned}
& y_{i}=k_{i} p r_{k} \\
& y_{i}=s_{i}+i_{i} \\
& i_{i}=y_{i} \frac{1+\tau}{p r_{i}} \\
& s_{i} p_{i}=\psi\left(s_{i} p_{i}+Y_{k,-1}\right) \\
& p_{i}=\frac{W_{k} N_{i}}{y_{i}}\left(1+\phi_{i}\right) \\
& N_{i}=\frac{k_{i}}{p r_{k} l_{k}} \\
& L_{i}=k_{i} p_{k}
\end{aligned}
$$

where $i_{i}$ is the quantity of produced capital good retained to ensure a production capacity growth equal to $\tau$ and $i_{s}$ is the remaining of output that is sold at price $p_{i}$.

The innovative firms sector starts producing in the next period, selling its capital to consumption good producers. The demand they face is made up of their own investment and of consumption good industry's investment $y_{i}=i_{c, i}+i_{i}$. Employment and unit costs follows the same rule as in the consumption good sector since the innovative firms use both kind of capital ${ }^{15}$. Growth of capital stock is fixed to $\tau$ until they enter the financial market, then it follows (2.72).

\footnotetext{
${ }^{15}$ The innovative firm uses both types of capital until the traditional capital bought in the first period of their life is fully depreciated.
} 


$$
\begin{aligned}
& g_{y i}=\eta_{i, 0}+\eta_{i, 1} u_{i}^{e}-\eta_{i, 2} r r_{l, i} \lambda_{i,-1}+\eta_{i, 3} q_{i,-1} \\
& g_{i, i}=\frac{g_{y i}}{p r_{i}}
\end{aligned}
$$

We assume that the innovative sector is not present at first on the stock market and enters the market only after 20 periods. Once it has entered the market, it follows the same rules as the other productive sectors to finance their desired investments. Before entering the financial market, all investments are financed through profits and loans ${ }^{16}$.

\subsection{Banking Sector}

Banks hold deposit accounts from both household sectors and lend cash to firms. We assume that banks always accommodate loans requests and that there are no non-performing loans until the bankruptcy of traditional capital producers. Banks do not have any leverage and thus cash deposits are always equal to loans. Banks' only source of income is the interests paid by firms. Banks do not have any operating costs and do not pay any interests on cash deposits by households. All profits are distributed as dividends to capitalists. We assume that banks charge different interest rates based on the risk perceived to lending to the different sectors ${ }^{17}$. Risk evaluation is proxied using the difference between an exogenously determined benchmark return rate $r_{b}$ and the average net-ofinterest return rate on capital generated during the last 5 periods (2.78)-(2.83).

$$
\begin{aligned}
& F D_{b}=r_{l, c} L_{c,-1}+r_{l, k} L_{k,-1}+r_{l, i} L_{i,-1} \\
& M_{s}=M_{w}+M_{c} \\
& L_{d}=L_{c}+L_{k}+L_{i} \\
& M_{s}=L_{d} \\
& \left.r_{l, c}=r_{l}\left(1+\frac{1}{1+\exp \left[\kappa\left(\overline{r_{c}}-r_{b}\right)\right.}\right)\right]
\end{aligned}
$$

\footnotetext{
${ }^{16}$ When creating a new firm, investors face the choice of how to finance their initial investment. Two solutions may be envisaged; either investors have recourse to bank credit or they use their own financial capital (a mechanism that may be labelled under the generic name of joint ventures). In this paper we analyze only the case of credit-financed firms. We feel however that the dynamics would not change much qualitatively if we allowed for joint ventures-financed firms. Given this choice, it is reasonable to assume that the innovative sector is not credit rationed, we assume that banks have already filtered investors and are then fully supporting the emerging firm, granting them as much credit as they need. Banks nonetheless discriminate between sectors via the interest rate they charge, see section 2.3.

${ }^{17}$ For more information on how banks set interest rates, see Gambacorta (2008).
} 


$$
\begin{aligned}
& r_{l, k}=r_{l}\left(1+\frac{1}{1+\exp \left[\kappa\left(\overline{r_{k}}-r_{b}\right)\right]}\right) \\
& r_{l, i}=r_{l}\left(1+\frac{1}{1+\exp \left[\kappa\left(\overline{r_{i}}-r_{b}\right)\right]}\right) \\
& \overline{r_{c}}=\frac{1}{5} \sum_{n=1}^{5} \frac{F_{c,-n}-r_{l, c,-n} L_{c,-(n+1)}}{p_{k,-(n+1)} k_{c,-(n+1)}+p_{i,-(n+1)} i_{c,-(n+1)}} \\
& \overline{r_{k}}=\frac{1}{5} \sum_{n=1}^{5} \frac{F_{k,-n}-r_{l, k,-n} L_{k,-(n+1)}}{p_{k,-(n+1)} k_{k,-(n+1)}} \\
& \overline{r_{i}}=\frac{1}{5} \sum_{n=1}^{5} \frac{F_{i,-n}-r_{l, i,-n} L_{i,-(n+1)}}{p_{k,-(n+1)} k_{i,-(n+1)}+p_{i,-(n+1)} i_{i,-(n+1)}}
\end{aligned}
$$

\section{RESULTS}

The model we just described is simulated using Mathematica ${ }^{18}$, with different scenarios. We identified a baseline scenario and then changed the value of some parameters in order to analyze the impact of these parameters. In the next subsection we analyze the dynamics of the model in the baseline scenario.

The following subsections will then go through different scenarios in which we modify the behavior of the various sectors and analyze the impact of these changes on the short and long-term dynamics of the economy at hand. Table 5, in appendix B, contains a summary of the values used for each scenario.

\subsection{The Baseline}

The simulation starts from a steady state situation and ends when a new steady state is reached.

During each simulation, the economy faces three different shocks: (i) the emergence of the innovative capital sector and the related increase of money due to the new credit accorded to entrepreneurs; (ii) the entry of the innovative sector in the stock market; (iii) the exit of the traditional capital good sector and the related drop in capitalists' wealth, due to non-performing loans by the traditional sector.

\footnotetext{
${ }^{18}$ The source code for the simulations can be requested from the authors.
} 


\subsubsection{The Rise of Innovators}

The first effect of the appearance of entrepreneurs (i.e. of the innovative sector) is a transitory rise in traditional capital sector output (period 21). Indeed, the new demand coming from entrepreneurs is, first of all, a demand for capital goods and labor. Entrepreneurs hire workers to produce their innovative capital good with the capital bought from the traditional sector. Employment thus rises not only as a direct consequence of the emergence of a new sector but also due to the increase in demand in the traditional sector. Consequently, together with employment and wages, demand for consumption goods also increases. Figure 3 shows the dynamics of outputs and employment during the baseline simulation.
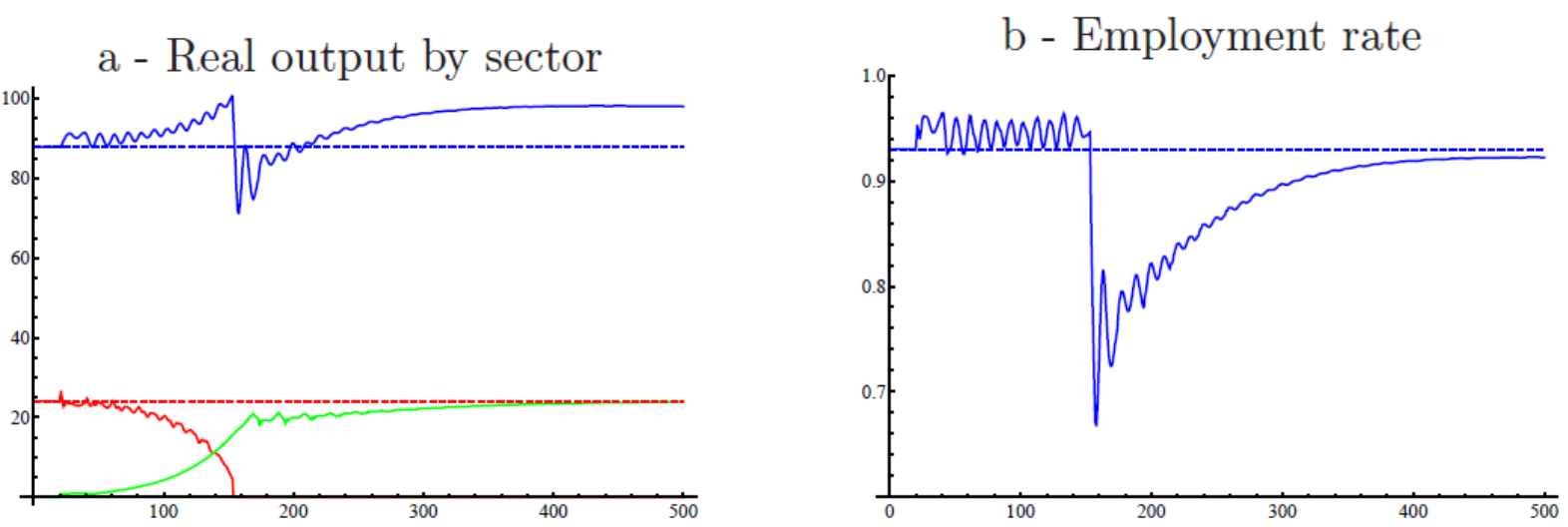

Figure 3: Graph a: Real output by sector: consumption sector (blue), traditional (red), and the innovative (green) capital sectors. Dashed lines are original levels. Graph b: Aggregate employment rate.

The rise in traditional capital demand is only temporary. Once entrepreneurs have set up their new production process, they start to sell it on the market. Since the innovative capital good is perceived as more profitable by the consumption sector (see figure 4), the innovative sector starts to win market shares from the traditional capital sector. 


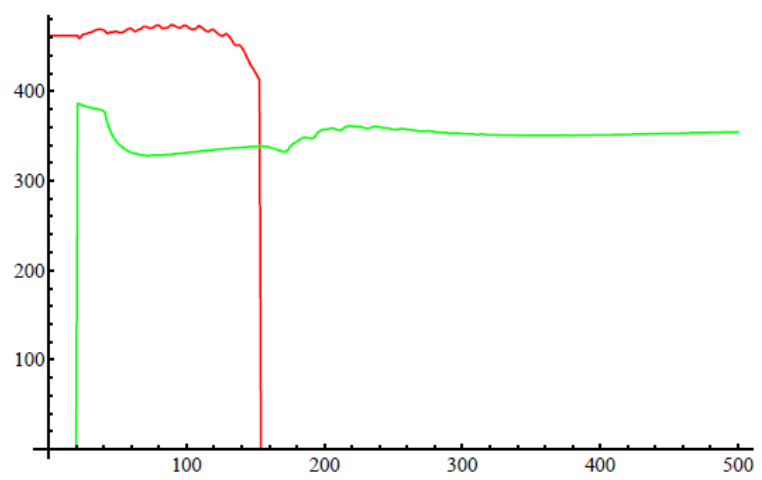

Figure 4: Cost of capital for the consumption sector defined as $p_{x} / p r_{x}, x=k, i$. Red and green lines are respectively costs of traditional and innovative capital.

However, figure 3.a shows that the overall demand for traditional capital goods remains fairly stable for several periods, fluctuating around the steady state level. This is due to two effects. The first one is that although the consumption sector would like to shift its demand towards the new more productive investment good, the innovative sector is still too small ${ }^{19}$ to fully supply the capital demanded, constraining the consumption sector to continue to invest in traditional capital. The second impact is caused by the increase in demand for consumption goods. Indeed, this increase in demand spurs the consumption industry to invest more than before. This increases the demand in capital goods, which cannot be covered by the innovative capital producers and thus trickles down to the traditional industry.
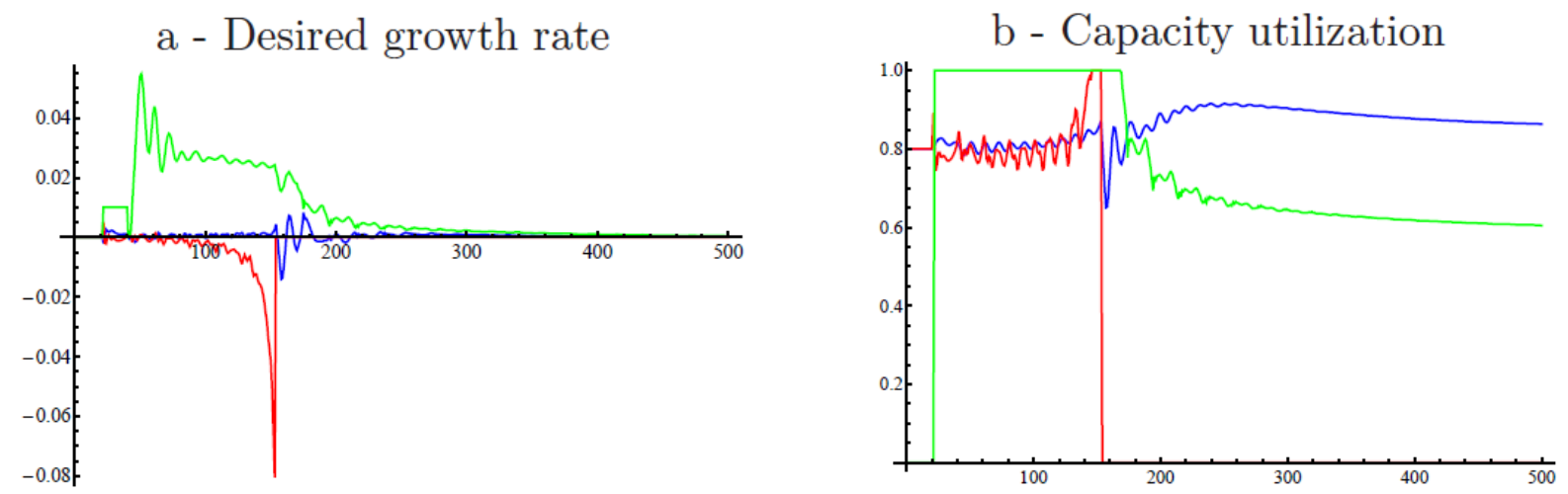

Figure 5: Graph a and b: Desired rate of growth of production capacity and capacity utilization by sector: consumption sector (blue), old (red), and new (green) capital sectors. When $g_{x}<0$, gross investment is nil.

\footnotetext{
${ }^{19} \mathrm{We}$ assumed that the innovative sector has a potential market share of $3 \%$ when it enters the market.
} 
Investment of the capital sector (the other component of the demand for old capital)

fluctuates around a rather constant value in the first stage of the simulation. To understand the mechanisms underlying these fluctuations, we have to look at the determinants of investment (see figures 5 and 6), and at the complex interactions between real and financial variables that takes place in this context. When the rate of capacity utilization fall under/over the 'standard' one (0.8), it induces traditional capital sector to decrease/increase investment. But investment also depends on Tobin's $\mathrm{q}^{20}$.
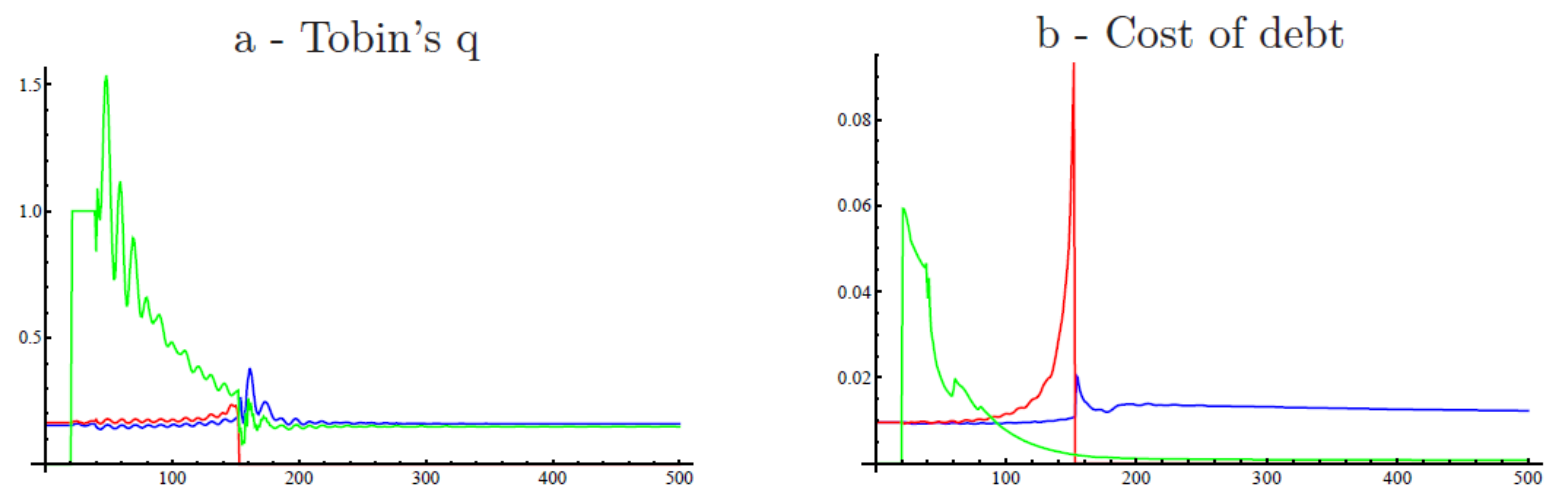

Figure 6: Graphs a and b represent the two arguments of the investment function, respectively: Tobin's $q$ and the product of the leverage rate by real interest rate on loans. Blue line for consumption sector, red and green for traditional capital sector and innovative sector, respectively.

When the innovative sector first appears, the ex-novo created money increases the financial wealth of investors. More liquidity comes to the stock market generating capital gains in both consumption and traditional capital sectors. This tends to increase their market capitalization, and thus the Tobin's q. The rise of the Tobin's q in turn should contribute to stimulate investment. However, when investment rises, distributed profits generally slack off as firms first use their retained earnings to finance investment, thus reducing the expected return on shares. Hence the market capitalization and the Tobin's q drop. On the contrary, when investment goes down, distributed profits may increase, positively affecting the expected rate of return on shares and then increasing the market capitalization and the Tobin's q of the sector ${ }^{21}$. Thus investment fluctuates as a consequence of the feedback effects between real and financial economy.

\footnotetext{
${ }^{20}$ The remaining argument of the investment function, that is the product of the leverage ratio for the real interest rate charged on loans, is instead roughly constant in this phase and thus plays a minor role.

${ }^{21}$ Notice that this could partially counteract the fall in the rate of capacity utilization thus mitigating the related fall of investment.
} 


\subsubsection{The Transition}

As the innovative firm continues to grow (in an exponential way, see figure 3.a), the situation for the traditional sector radically changes. The innovative sector is able to provide a constantly increasing portion of the demand coming from the consumption sector. This reduces the demand for traditional capital, thus lowering its rate of capacity utilization. Consequently, traditional capital sector investment shrinks ${ }^{22}$. Furthermore, in period 40 the innovative firm enters the financial market. The first consequence is an increase in the volatility of financial wealth, due to higher volatility of capital gains in traditional sectors triggered by the appearance of a new asset, that in turn affects the expectations on future financial wealth (and then future capital gains) ${ }^{23}$.
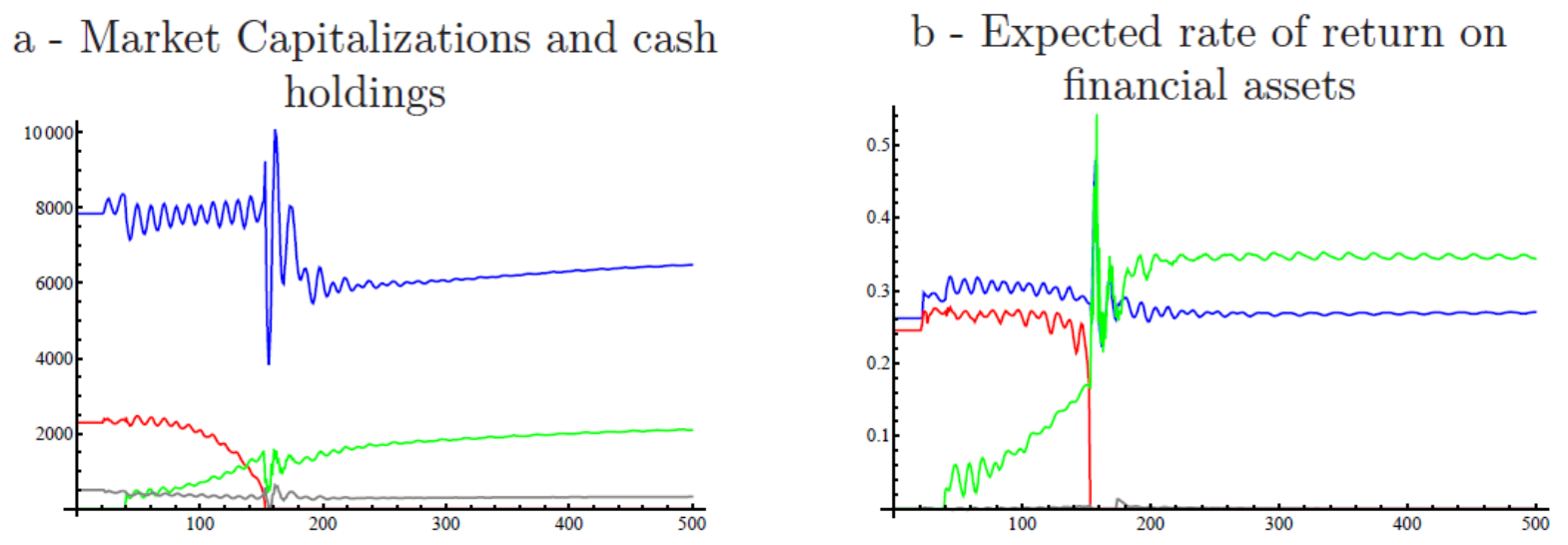

Figure 7: Graph a shows the market capitalization of each sector and the cash holdings. It represents how capitalists' financial wealth is distributed among the different assets. The blue, green and red lines are respectively the consumption, traditional capital and innovative sectors, the gray one indicates the amount of financial wealth held in the form of money. Graph b shows the expected rate of return of each financial asset: the rate of return of money (gray line) depends on inflation while the expected rate of return on the stocks of the consumption (blue), traditional capital (red) and innovative (green) sectors depends on past capital gains, past distributed profits and past gross profits.

\footnotetext{
${ }^{22}$ Considering the depreciation of capital, the traditional capital sector net-investment turns negative.

${ }^{23}$ Furthermore, since the stock of financial wealth is now distributed among four assets, rather than the previous three, both the money holdings of capitalists and the stock prices of the traditional sectors lightly decrease.
} 
Very soon, the innovative sector market capitalization starts to rise, pulled by the rapid increase in both gross and distributed profits, attracting investors. The innovative sector Tobin's q then significantly rises, as shown by figure 6.a. At the same time, the innovative sector has used the money obtained by its IPO to lower its level of leverage ${ }^{24}$. Finally, as profits grow, the perceived reliability of the innovative firms grow, inducing banks to charge them a lower interest rate. All these factors, together with rate of capacity utilization constantly pushed to one, generate a boom in the investment of the innovative sector.

The consequent rise of the innovative sector stock of capital then determines a drop of its Tobin's q even if this effect is mitigated by the ever-rising market capitalization of the innovative sector (pushed by profits). This should cause a slowdown of investment. However, the constant reduction of the leverage ratio compensates for the decrease of the Tobin's q. Indeed, while the capital stock of the innovative sector is rapidly increasing, loans remain constant or increase less than proportionally. The innovative firm thus continues to grow in an exponential way. In three periods $(68,77$, and 99), the level of investment is so high that retained earnings are not sufficient to fund it and firms are forced to ask for external finance. It is interesting to note that in these three cases, the preferences of the innovative sectors move from external equity finance to bank loans as a consequence of the gradual reduction in the interest rate charged by banks ${ }^{25}$.

While the market capitalization of the consumption sector, after the initial drop, fluctuates around a substantially constant level, traditional capital sector market capitalization starts to fall (see figure 7.a). The main cause has to be found in the process of Schumpeterian competition occurring in the real economy. As the production capacity of the innovative sector continues to grow, the demand for traditional capital continues to fall. Investment of the traditional sector thus falls too. The stock of capital decreases since a constantly increasing portion of depreciated capital is no longer replaced.

The market capitalization of the traditional capital sector progressively falls as a consequence of two facts: first, the decline of the stock of capital of the traditional sectors and the parallel rise in that of the innovative sector induces a change in the coefficients of the portfolio choice equations (see section 2.1.2). Hence $\lambda_{30}$ grows while $\lambda_{40}$ declines. At the same time, the fall in profits (gross and distributed) worsens the expected return of traditional capital sector shares,

\footnotetext{
${ }^{24}$ This assumption is very reasonable since the innovative sector has bought its initial stock of capital and has hired workers using only external finance, that is bank credit. Thus its leverage ratio, initially equal to one, was by far the highest in the system, almost five times that of other sectors, see figure 6.b. By using the money collected in its initial public offering to repay part of his debt, the innovative sector is trying to move towards a more "normal" situation. ${ }^{25}$ This preference is represented by the coefficient $\varphi$, defining the share of the overall externally financed investment that the sector desire to finance by new emissions of shares. Indeed $\varphi$ passes from 0,75 to 0,6 and then to 0,45 .
} 
thus generating negative expectations about capital gains which in turn further reduces expected returns, giving rise to a vicious circle (see figure 7.b). Beside the fall in the stock prices of the traditional capital sector, the contraction of its capital stock blows up the leverage ratio (given that the stock of loans remains constant). In the meanwhile, the unrelenting reduction of profits increases the interest rate asked by banks, which now perceive the higher riskiness associated to traditional capital sector. This exerts a huge impact on investment. In the periods between 130 and 150, both the Tobin's $q$ and the rate of capacity utilization sharply increase as a consequence of the dramatic fall in the capital stock. This should increase investment, all other conditions being equal. Nevertheless this does not happens since the parallel rise of both the leverage ratio and the rate of interest is so drastic ${ }^{26}$ that it more than offsets the potential positive effect of Tobin's q and $u_{k}$.

\subsubsection{The Fall of Obsolete Industries}

In period 159, both the demand for traditional capital coming from the consumption sector and the investment of the traditional capital sector itself has disappeared, thus forcing the old capital sector to exit the market. The default of the traditional capital sector in turn induces a loss in the banking sector related to the non-performing loan $L_{k}$. This loss is transferred to bank profits that become negative, which in turn causes a negative income for capitalists, and a consequent drop of capitalist wealth ${ }^{27}$, see figure 8 .
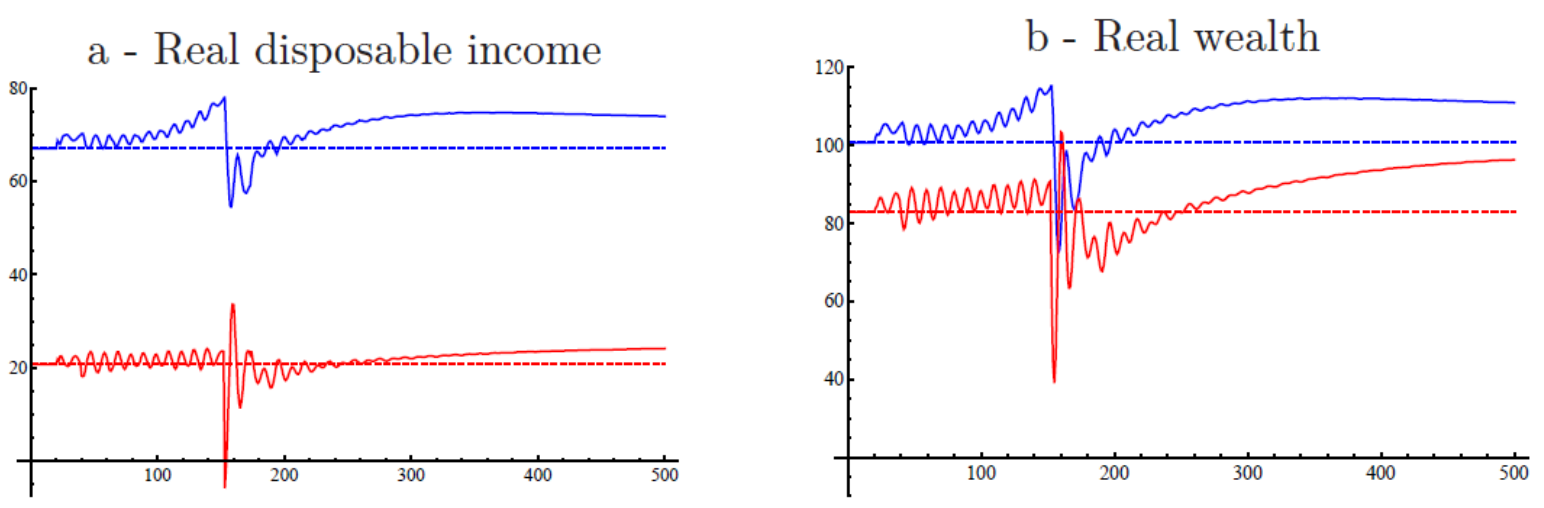

Figure 8: Graph a, b: Total real disposable income and real wealth of wage earners (blue) and capitalists (red). The dashed lines represent original levels.

\footnotetext{
${ }^{26}$ The interest rate in fact increased by approximately $40 \%$ compared to that charged at steady state, while the leverage ratio increases up to ten times between period 100 and period 159.

${ }^{27}$ Since current disposable income is negative, capitalists have to use their wealth to consume. Consumption indeed does not fall immediately, together with disposable income. Since consumption in period 159 is a function of expected disposable income (defined as the average of disposable income over the last 4 periods) and past wealth, the capitalists' consumption remains roughly constant in period 159 and shrinks only in the next period.
} 
This exerts a huge impact on the consumption sector. Demand of consumption goods shrinks heavily (figure 3.a) as a consequence of the contraction of capitalists' consumption, and this effect, adding to the job losses in the traditional capital sector, causes unemployment to increase dramatically (figure 3.b). Wage earners disposable income and wealth shrink (figure 8.a and b) further reducing consumption. In essence, the fall in demand induces the consumption sector to reduce its production capacity. At the same time, the huge loss of wealth by capitalist causes a boost of the stock market, thus reducing the market capitalization of the consumption sector and its Tobin's q. Consequently, $g_{c}$, what has been positive for many years, now turns negative. Notice that the innovative sector instead continues to grow even after the shock for some periods, see figure 3.a. The reason for this inertia has to be found in the fact that the consumption good sector has invested a lot in the past, increasing its capital stock. This, together with fact that the capital depreciation function is defined as an exponential function of the age of capital, makes the depreciation of $k_{c}$ and $i_{c}$ increase. This explains why the demand for innovative capital continues to grow for a while, despite the fact that the consumption sector desires to reduce its production capacity. This also helps to explain why the fall in market capitalization and the volatility in share price induced by the default of the traditional sector is less pronounced for the innovative sector than for the consumption one (7.a).

However this shock is only temporary. In fact the banking sector makes negative profits only for one period and $F D_{b}$ turns back positive in the next period. Thus $y d_{c}$ recovers. This tendency is only partially compensated by the negative capital gains related to the contraction of capitalists' financial wealth. After the initial drop, employment (and thus the disposable income of workers) starts to recover, also as a consequence of the inertial growth of the innovative sector. Before converging to a new steady state, the economy experiences a period of high volatility mainly due to a mismatch in the timing characterizing the fall/rise of disposable income and wealth and the fall/rise of consumption: when disposable income goes down consumption takes more time to decrease because expected income is based on the past. Since consumption is higher than actual disposable income, the stock of wealth tends to decrease. When, on the contrary, disposable income recovers, consumption tends to remain at a lower level for some time, thus increasing wealth. Notice that, in the case of capitalists, this volatility is exacerbated by the fact that their disposable income depends also on their stock of wealth via capital gains.

This volatility, however, tends to fade as the expectations made by capitalists and workers about their disposable income and wealth are gradually revised, thus approaching their correspondent real values. The system then converges to the new steady state position. 


\subsubsection{Towards a New Steady State}

A higher level of output characterizes the new steady state. While the capital sector real output seems to converge to the previous steady state value, real output has significantly increased for the consumption sector 3.a. However, the capital sector now produces a more productive investment good. In the new steady state situation, both capitalists and wage earners show a higher level of real income (figure 8.a) and real wealth (figure 8.b), although a slight redistribution in favor of capitalists has taken place. The employment rate is about $92.3 \%$ slightly below the original level (figure 3.b). This fact is quite interesting since it means that the new technology has definitely been labor-saving even assuming a constant capital-labor ratio, equal to the one characterizing the old technology.

In the convergence towards the new steady state position, the investment function obviously plays a central role. From this point of view, it's interesting to note that while the Tobin's q of both productive sectors converge to their original levels ${ }^{28}$ (figure 6.a), this does not happen for the leverage ratios and the rate of capacity utilization (figures 5.b and 6.a). Indeed, a steady state is reached even if the rate of capacity utilization stabilizes at a different level from that considered "standard" (in our model 0.8), which is the target rate. At the end of our simulation the rate of capacity utilization is above the target for the consumption sector and significantly below for the innovative capital sector. But net investment does not diverge from the steady state zero level since the leverage ratio (higher for the consumption sector, significantly lower for the innovative sector) compensates for this discrepancy.

The dynamics just presented show that the process of Schumpeterian competition among the two capital sectors is going hand in hand with the process of structural change of the economy. Old traditional capital has been progressively substituted by the new more innovative one, thus pushing down the unitary costs of production in both the innovative and consumption sector. At the same time this process of "creative destruction" has pushed the traditional capital sector out of the market under the competitive pressure of entrepreneurs who finally come to dominate the market.

\subsubsection{Dynamics at Hand}

Our analysis, based on the SFC approach, highlights the complex interaction between the process of structural change taking place in the real economy and the evolution observed on financial markets. Indeed, the dynamics of the model are definitely driven by two fundamental processes:

\footnotetext{
${ }^{28}$ Or rather, the consumption sector q converges to its original value, the innovative sector Tobin's q converges to the original value of the traditional capital sector.
} 
first, the replacement of the old capital by a new, more productive capital, and second, financial instability arising from the emergence of a new sector. The first process is a rather slow one: the consumption firm is replacing its old capital by the new one because it is perceived to be more profitable. However, at first the output of the innovative firm is not large enough to fulfill the demand by the consumption sector. The innovative sector is thus slowly building its own production capacity while selling the remaining part of its output to the consumption good producers.

The second process, on the other hand, is rather short. Indeed, the wealth and income effects due to the introduction of new money are directly realized by both household sectors and this drives short demand cycles. Because the introduction of the innovative sector is a unique event, expectations are not met (at first they are too low and then they are to large), creating the first wave of financially-induced short cycles. However, the second shock due to the entrance of the innovative firms into the stock market brings again some financial instability, which will lead to some more waves of cycles. Finally, the double shock when the traditional firms exit both the financial market and the real market, creating a massive loss to banks, which is directly reflected in capitalist's wealth, leads to some more financial instability.

Financial instability is transmitted to the real sector via two behaviors: the consumption decision by capitalists which is based on real wealth and disposable income (which contains distributed profits and capital gains) and the investment function where Tobin's q impacts firms decision to increase or not their production capacity. In turn real economy affects financial dynamics via gross and distributed profits on one hand, and via changes in nominal wealth on the other.

\subsection{Path Dependency}

The model allows us to highlight that importance of time. Indeed, the following experiment allows us to observe the phenomenon of path dependency. By changing the period in which the innovative firms enter the financial market, that is 10 periods after their entry into the real market, instead of 20, we observe a different steady state, even if all the other techno-financial parameters are identical. Thus the velocity of change matters also, not only the objective. Figures 9 and 10 show the real output, market capitalization, real disposable income, and employment. From these graphs, it seems clear that all variables are following the same trends with a lag. The lag slowly reduces as the economy reaches its steady state. 

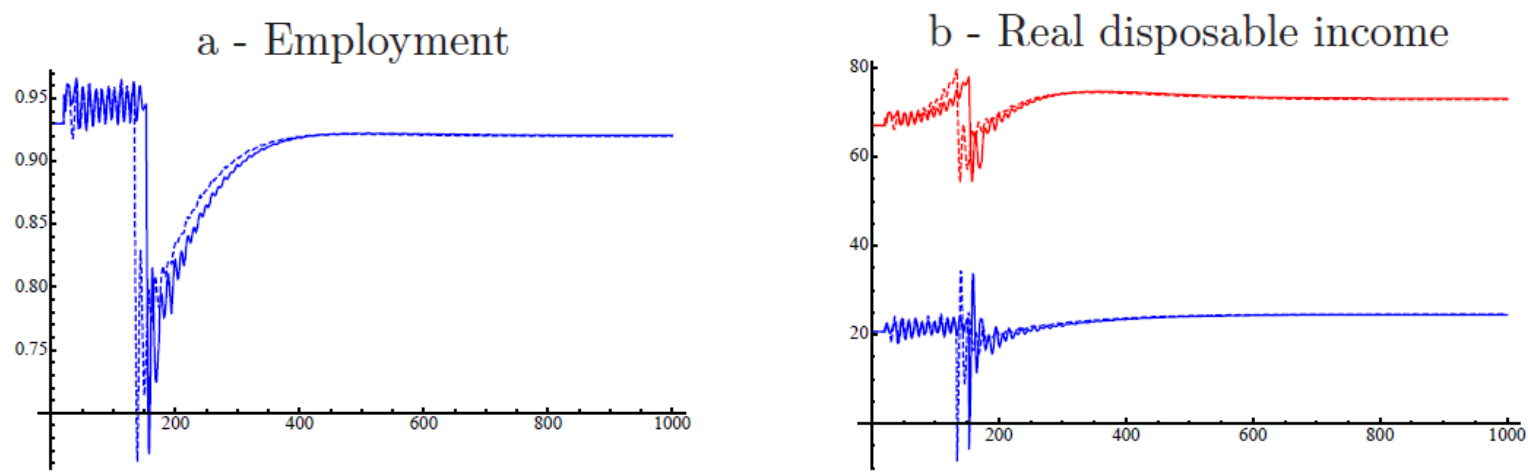

Figure 9: Employment and real disposable income in the baseline scenario (solid lines) and in the PathDep scenario (dashed lines). Both time series show a lag slowly decreasing between baseline and PathDep. For real disposable income, blue is capitalists and red is wage earners.

a - Market capitalisation

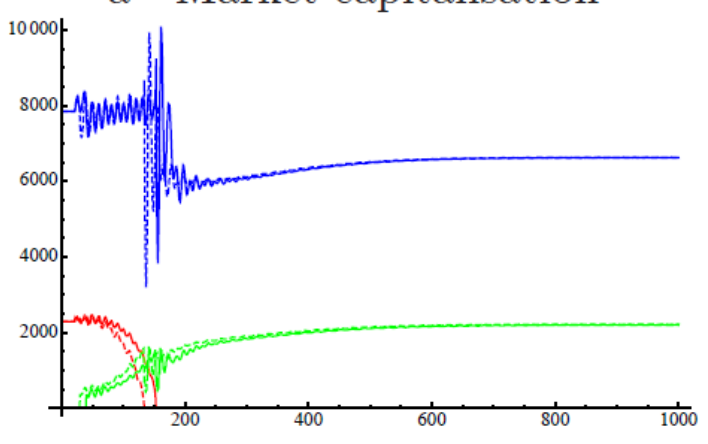

b - Real output

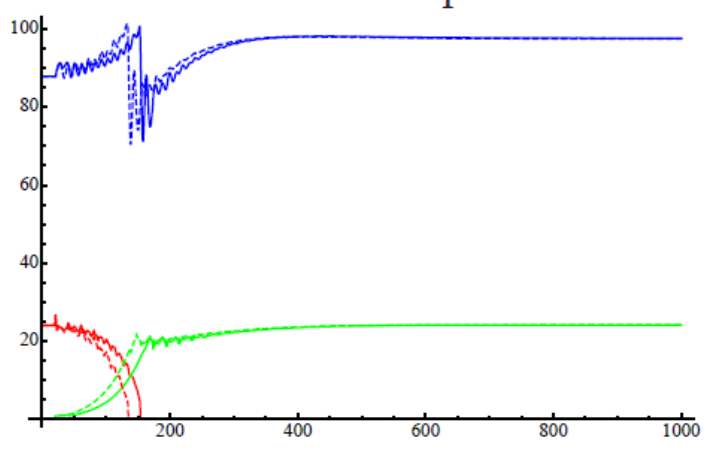

Figure 10: Real output and market capitalization in the baseline scenario (solid lines) and in the Patched scenario (dashed lines). Both time series show a lag slowly decreasing between baseline and PathDep. Blue is the consumption sector, red the traditional capital one, and green the innovative one.

However, what is interesting is that the steady state values obtained for this new scenario, called PathDep, are different from the baseline steady state values, as shown in Table 2. 


\begin{tabular}{|l|cc|}
\hline & Baseline & PathDep \\
\hline Employment & -0.989404 & -1.07541 \\
Real consumption output & 11.2002 & 11.0486 \\
Wage earners real disposable income & 9.06761 & 8.70943 \\
Capitalists real disposable income & 18.0844 & 18.6006 \\
Capitalists real wealth share & 4.37319 & 4.79523 \\
\hline
\end{tabular}

Table 2: Percentage change in value from initial steady state to final steady state: in the PathDep scenario, employment, real output in the consumption and wage earners real disposable income sector have a lower value. On the other hand capitalists real disposable income and real wealth, as a share of total real wealth, have increased. This shows the path dependency of technological change steady state.

The fact that the innovative firms enter the stock markets 10 periods before than in the baseline scenario implies that the traditional sector goes bankrupt 19 times before. Furthermore, this implies a redistributive impact between real output of consumption goods and capital goods, in favor of capital producers. This redistributive impact is also observed between capitalists and wage earners, in the favor of capitalists. These results highlight the importance of path and timing of the emergence of a new technology. The benefits or disadvantages resulting from the emerging new productive structure could be modified by a change in timing, leaving some policy space for government.

\subsection{Distributive Impacts}

This section will analyze the distributive impacts that the financial side of the economy has on real disposable income and real output. The scenario, called InterestRate, allows for banks to be more discriminative by using a steeper curve to fix the interest rate charged, see figure 11.a. 


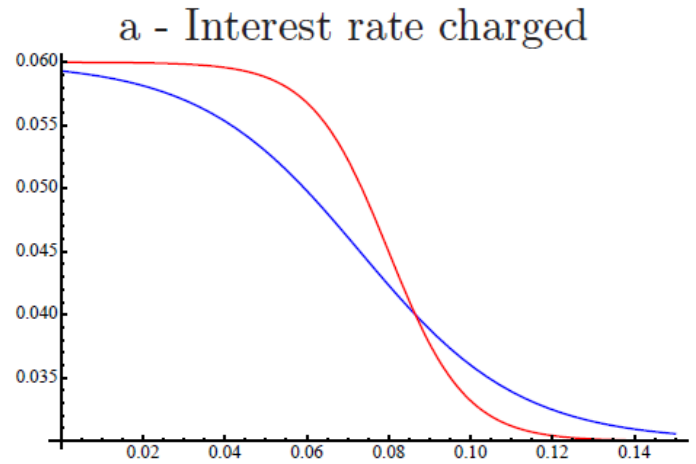

b - Investment by consumption firm

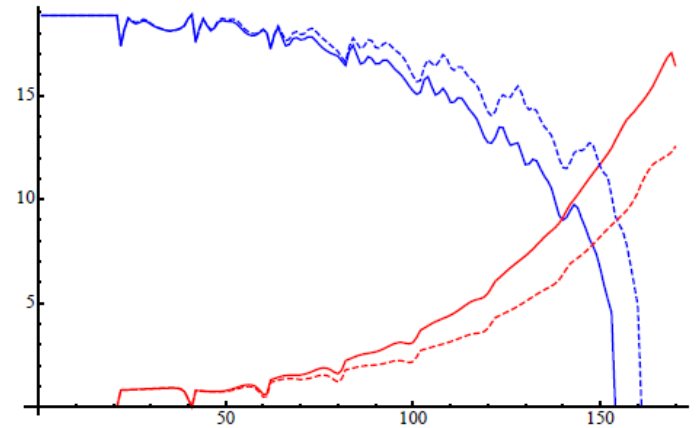

Figure 11: The InterestRate scenarios allows for a change in the interest rate-fixing curve. Figure a shows that in the InterestRate scenario, the curve is steeper allowing banks to be more discriminative between high profit firms and low profit ones. Figure b shows how, in the short-run, a slow growing innovative firm lets the traditional firms live longer by forcing consumption good producers to invest more in traditional goods.

The main results of this experiment allow us to see that the traditional sector remains longer in the market (it exits at period 160 instead of 153) and the in the long run, the propensity to charge higher interest rates implies a redistribution from capitalists to wage earners and from capital good producers towards consumption good producers, see figure 12.
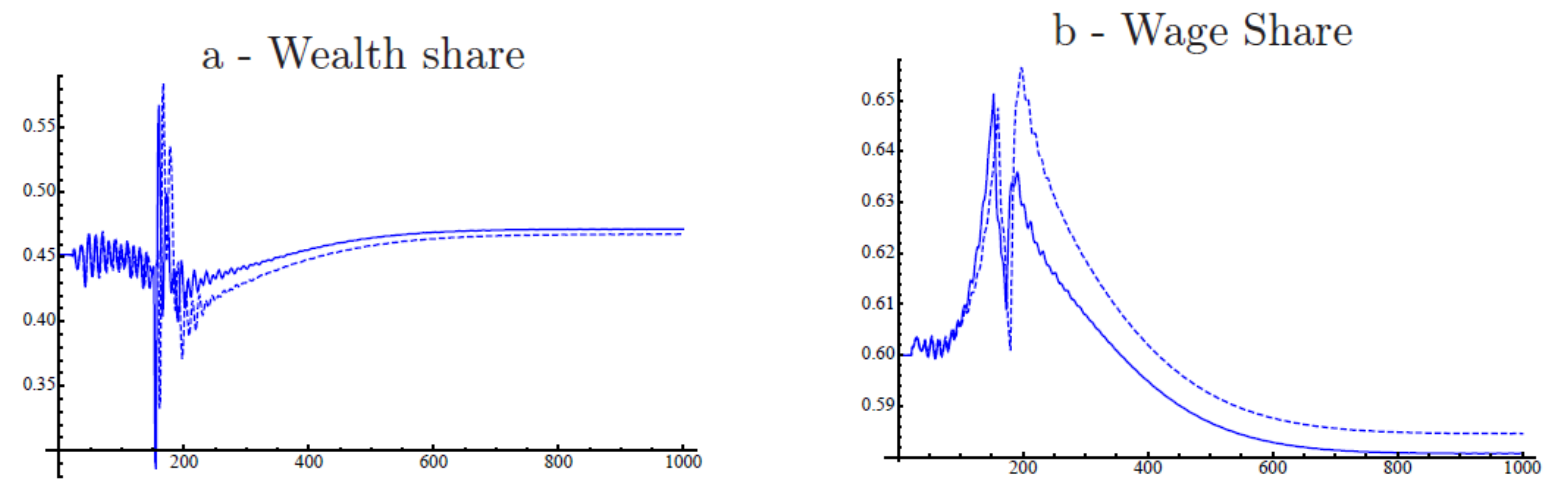

Figure 12: The InterestRate scenarios allows for a change in the interest rate-fixing curve. The long-run steady state shows that both the wage share and wealth share are larger in the InterestRate scenario than in the baseline one.

By being more discriminative, banks are reducing the growth of innovative firms on the short run and allows for traditional firms to live longer. Figure 11.b shows how, in the InterestRate scenario, the lower rate of growth of the innovative firms forces consumption good producers to invest more and longer in traditional capital goods. However, the short-run impact of this different 
interest rate policy by banks also has an impact on the long run. Not only because, as we have already seen, the long-run steady state is path dependent; but also because the whole financial structure is impacted by interest rates.

As seen in the previous section, the long-run steady state depends on a few dynamic equations. The interest rates play a direct role in the growth function via the leverage costs. This explains a restructuration in the balance sheets of firms; showing a slight increase in leverage and variation in Tobin's q's and, on the real side, lower capital stocks and lower capacity utilization rates.

Finally, this change in the interest rate decision implies a redistributive impact from capitalists towards wage earners. Indeed, the wage share is larger in the InterestRate steady state than in the baseline case but also the wealth share of wage earners is larger. Figures 12.a and 12.b show the dynamics of the wage share and wealth share.

\subsection{Productivity Gains, More Than Just a Shock}

This section analyzes the choices made by the innovative firm in depth. We show the possibility of failure of technological change where the innovative firm, even when producing a more efficient capital does not succeed in remaining in the market. We changed the parameters determining the entrance of the innovative firms, that is the target market share $(\rho)$ when entering the market and the fixed rate of growth $(\tau)$ until entering the financial market. In that scenario, called Bigger and Faster, $\rho=0.05$ instead of 0.03 and $\tau=0.013$ instead of 0.01 . We observe that in that case, the innovative firm fails after 61 periods and leaves the market. 
a - Innovative output

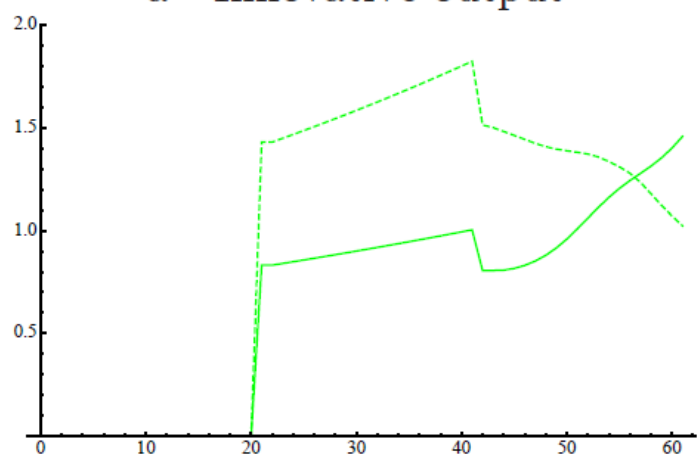

c - Innovative leverage

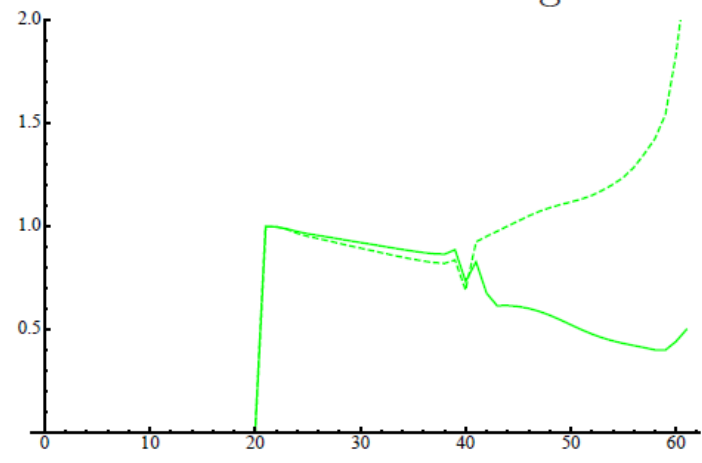

b - Innovative profits

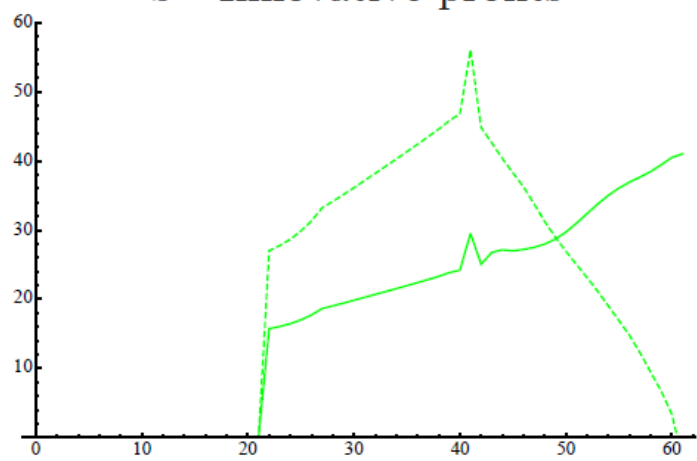

d - Innovative Tobin's q

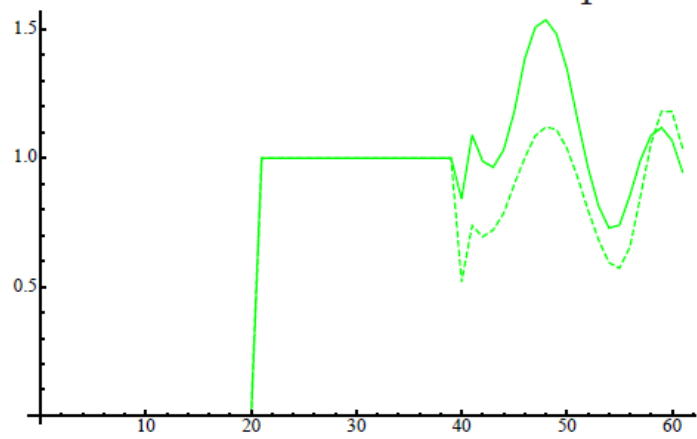

Figure 13: The Bigger and Faster scenario simulates an innovative firm entering with a larger market share and with a higher rate of growth in the first 20 periods. Graph a shows that output grows at first at a faster pace but when the innovative firm enters the financial market (period 41) the output growth turns negative forcing profits (graph b) to decrease until reaching 0 in period 61 . Two financial indicators, the leverage level in graph $c$ and Tobin's $q$ in graph d show that after entrance in the financial market, the financial situation of the innovative firm deteriorates triggering a downward process leading to bankruptcy.

Figure 13 shows the results of scenario Bigger and Faster. The innovative sector grows faster for the 20 periods before its entrance on the stock market. However, the funds it can raise on the financial market are lower respectively to the size of the firm, implying a lower Tobin's q and a leverage, which at first is slightly lower. However, the lower Tobin's q depresses the investment function, which causes a decrease of the capital stock. This in turn impacts the leverage, which starts growing, leading to a further decrease in investments. This will also depress profits since it can sell less capital to the consumption good producers.

The whole dynamics starts snowballing until the innovative firm stops making profits and exits the market. This scenario shows the importance of the initial market capitalization. Even when the innovative firm is making more profits, as in the Bigger and Faster case, if it fails to raise enough 
funds the whole growth dynamics is disrupted and leads to a massive failure of the innovative sector. Furthermore, the scenario also shows the possibility for an innovation not to be adopted, due to the badly designed entrance. The same innovation succeeds in entering the market in the baseline scenario while it does not in the Bigger and Faster scenario.

\section{CONCLUSIONS AND FURTHER DEVELOPMENTS}

The experiments performed with the model presented in the paper have shown the importance of the link between finance and innovation in shaping the long-term business cycle triggered by technological change. In particular, the model showed how the instability in the financial and real economy observed in the simulations might arise as a consequence of the way in which the economic system assimilates a wave of innovations, without reference to any psychological variable of economic agents. Irrational exuberance, frenzy, gregarious behavior are often called into question, with good reason, to explain the emergence of speculative behaviors generating, in turn, boom and bust phenomena. Instead, in the model, instability arises from Schumpeterian competition between the old actors of the economy and the entrepreneurs, that is from what Schumpeter called the "creative destruction" process.

Therefore, this work represents a good starting point for developing a consistent approach to the study of technological dynamics, capable of linking the evolution of real and financial variables, analyzing the complex feedback effects between these two dimensions. However, precisely because this is only the first step in this direction, the model is affected by some major limitations. Although the structure and dynamics of the model are already quite complex, it still rests on a number of simplifying hypotheses and ad hoc assumptions about the behaviors of the different sectors and the changes in parameters related to the appearance and disappearance of whole sectors in the real and financial markets. These assumptions were made necessary, first, not to further complicate the analysis, and second, for the constraints imposed by the use of an aggregate model. Furthermore, the adoption of a highly aggregate perspective, while helping to highlight some important mechanism underlying the technology rooted cycle, makes the dynamic of the model particularly crude and thus partially unrealistic. This feature is also exacerbated by two facts, again related to the aggregate nature of the model: first, we exclude the possibility that some of the old capital producers may realize what is going on and try to convert their production, thus becoming imitators, generating a secondary wave of innovations (a possibility already considered by Schumpeter himself). Second, we chose to focus on a one-shot innovation process, arising from a situation of 
absence of development and ending in a new steady state position. Hence we do not consider the role of incremental patterns of innovation in the short-medium run. Furthermore, in reality, every great surge of development, based on a set of radical innovations, relies on and overlaps the previous one so that a steady state is never reached.

In order to overcome these limits we have to abandon the rigidity and the constraints imposed by the adoption of pure macroeconomic perspective in favor of a more flexible framework, maintaining at the same time the rigorous accountability rules implied by the SFC approach. We believe that the agent-based micro-founded model (ABM) might prove suitable for this purpose. A first advantage of this model is that they avoid all the simplifications required in order to find an analytical solution for the steady state. Above all, by disaggregating the sectors of our economy into the agents that compose them, they introduce more adaptive and heterogeneous behaviors. In ABM models agents react to their environment thus allowing them to handle complex feedback effects between the macro and the micro levels. Heterogeneity emerges endogenously as even originally similar agents may react in different way to the stimuli coming from the economic environment. Thanks to their flexibility and their ability to handle a wide range of complex non-linear behaviors, ABM has already proven to be well suited to study innovation processes and to analyze the functioning of financial markets ${ }^{29}$. Finally, it must be stressed that in recent years various attempts to provide a micro-foundation of SFC through an AB methodology has been made ${ }^{30}$. These contributions provide a useful basis for further developing the present work.

\footnotetext{
${ }^{29}$ For a review on these two fields see respectively Dawid (2006) and Lebaron (2006).

${ }^{30}$ See Kinsella et al. (2011) and Seppecher (2010) for two examples of SFC-ABM models and Bezemer (2011) for a call to use these models.
} 


\section{REFERENCES}

Accoce, J., and T. Mouakil. 2005. "The Monetary Circuit Approach: A Stock-flow Consistent Model." In Hein, E. and A. Truger, eds., Money, Distribution and Economic Policy: Alternatives to Orthodox Macroeconomics. Edward Elgar Publishing.

Bezemer, D. J. 2011. “Causes of Financial Instability: Don’t Forget Finance.” Working Paper 655. Annandale-on-Hudson, NY: Levy Economics Institute of Bard College.

Bottazzi, G., A. Secchi, and F. Tamagni. 2008. "Productivity, Profitability and Financial performance." Industrial and Corporate Change, 17-4:711-751.

Brainard, W. C., and J. Tobin. 1968. "Pitfalls in Financial Model Building." American Economic Review, 58(2):pp. 99-122.

Brown, J. R., S. M. Fazzari, and B.C. Petersen. 2009. "Financing Innovation and Growth: Cash Flow, External Equity, and the 1990s R\&D Boom.” The Journal of Finance, 64(1):151-185.

Castellacci, F. 2008. "Innovation and the Competitiveness of Industries: Comparing the Mainstream and the Evolutionary Approaches." Technological Forecasting and Social Change, 75(7):984 - 1006.

Dawid, H. 2006. "Agent-based Models of Innovation and Technological Change.” In Handbook of Computational Economics, Vol.2. Amsterdam: North Holland.

Delli Gatti, D., E. Gaffeo, and M. Gallegati. 2010. “Complex Agent-based Macroeconomics: A Manifesto for a New Paradigm.” Journal of Economic Interaction and Coordination, 5-2:111-135.

Dos Santos, C. H. 2006. "Keynesian Theorizing During Hard Times: Stock-flow Consistent Models as an Unexplored Frontier of Keynesian Macroeconomics." Cambridge Journal of Economics, 30(4):541-65.

Eichner, A. S. 1976. The Megacorp and Oligopoly: Micro Foundations of Macro Dynamics. Cambridge University Press.

Fazzari, S., R. Hubbard, and B. Petersen. 1988. "Financing Constraints and Corporate Investment." Brookings Papers on Economic Activity, 1:141 n 195.

Fazzari, S. M. and T.L. Mott. 1986-1987. "The Investment Theories of Kalecki and Keynes: An Empirical Study of Firm Data, 1970-1982.” Journal of Post Keynesian Economics, 9(2):171-187.

Foley, D. 1975. On Two Specifications of Asset Equilibrium in Macroeconomic Models." Journal of Political Economy, 83(2).

Gambacorta, L. 2008. “How Do Banks Set Interest Rates?” European Economic Review, 52:792-819.

Godley,W. and M. Lavoie. 2007. Monetary Economics An Integrated Approach to Credit, Money, Income, Production and Wealth. New York: Palgrave Macmillan.

Graziani, A. 2003. The Monetary Theory of Production. Cambridge: Cambridge University Press.

Haig, R. M. 1921. "The Concept of Income - Economic and Legal Aspects." in The Federal Income Tax, pages 1-21. New York: Columbia University Press. 
Kinsella, S., M. Greiff, and E.J. Nell. 2011. "Income Distribution in a Stock-flow Consistent Model With Education and Technological Change." Eastern Economic Journal, 37:134-149.

Lavoie, M. 2004. "Circuit and Coherent Stock-flow Accounting.” in Arena, R. and N. Salvadori, eds. Money, Credit, and the Role of the State: Essays in Honour of Augusto Graziani, pp. 136-151. Ashgate: Aldershot. 1992. Foundations of Post-Keynesian Economic Analysis. Aldershot, UK: Edward Elgar.

Lavoie, M. and W. Godley. 2001-2002. "Kaleckian Models of Growth in a Coherent Stock-flow Monetary Framework: A Kaldorian View.” Journal of Post Keynesian Economics, 24(2):277-311.

Lazonick, W., M. Mazzucato, P. Nightingale, and S. Parris, S. 2010. "Finance, Innovation \& Growth - State of Art Report." Finnov Discussion Paper, 1.6:44.

Lebaron, B. 2006. "Agent-based Computational Finance." in Handbook of Computational Economics, Vol.2. by L. Tesfatsion and K.L. Judd, eds. Amsterdam: North Holland.

Mazzucato, M. 2003. "Risk, Variety and Volatility: Growth, Innovation and Stock Prices in Early Industry Evolution." Journal of Evolutionary Economics, 13:491-512.

Mazzucato, M. and M. Tancioni. 2010. "Innovation and Stock Price Volatility." in 13 th International Schumpeterian Society Conference, Aalborg.

Meyers, S. 1984. “Capital Structure Puzzle.” Journal of Finance, 39-3:575-592.

Mina, A., H. Lahr, and A. Hughes. 2011. “The Demand and Supply of External Finance for Innovative Firms.” Finnov Discussion Paper, 3.5:39.

O’Sullivan, M. 2000. "The Innovative Enterprise and Corporate Governance." Cambridge Journal of Economics, 24-4:393-416.

Pastor, L. and P. Veronesi. 2009. “Technological Revolutions and Stock Prices.” American Economic Review, 99-4:1451-1483.

Perez, C. 2010. “Technological Revolutions and Techno-economic Paradigms." Cambridge Journal of Economics, 34(1):185-202.

2009. "The Double Bubble at the Turn of the Century: Technological Roots and Structural Implications." Cambridge Journal of Economics, 33(4):779-805.

2002. Technological Revolutions and Financial Capital: The Dynamics of bubbles and Golden Ages. Cheltenham: Elgar.

Robinson, J. 1969. “A Further Note.” The Review of Economic Studies, 36(2):260-262.

Schumpeter, J. A. 1964/1939. Business Cycle. A Theoretical, Historical and Statistical Analysis of the Capitalist Process. abridged edn, New York: Mc-Graw Hill.

Schumpeter, J. A. 1934/1912. The Theory of Economic Development. Cambridge, MA: Harvard University Press. 
Seppecher, P. 2010. "Flexibility of Wages and Macroeconomic Instability in an Agent-based Computational Model with Endogenous Money." Workshop on Economic Hetergeneous Interacting Agents. ESHIA/WEHIA.

Simons, H. C. 1938. Personal Income Taxation: The Definition of Income as a Problem of Fiscal Policy. Chicago, Il: Chicago University Press.

Steindl, J. 1952. Maturity and Stagnation in American Capitalism. Blackwell.

Zezza, G. 2004. "Some Simple, Consistent Models of the Monetary Circuit.” Working Paper 405. Annandale-on-Hudson, NY: Levy Economics Institute of Bard College. 


\section{A. Transaction Flow Matrix}

\begin{tabular}{|c|c|c|c|c|c|c|c|c|c|c|c|}
\hline & \multirow[t]{2}{*}{ Wage earners } & \multirow[t]{2}{*}{ Capitalists } & \multicolumn{2}{|c|}{ Consumption } & \multicolumn{2}{|c|}{ Capital } & \multicolumn{2}{|c|}{ Innovative } & \multicolumn{2}{|c|}{ Bank } & \multirow[t]{2}{*}{$\Sigma$} \\
\hline & & & Current & Capital & Current & Capital & Current & Capital & Current & Capital & \\
\hline Consumption & $-C_{w}$ & $-C_{c}$ & $+C$ & & & & & & & & 0 \\
\hline Traditional investment & & & & $-I_{c, k}$ & $+I_{k}$ & $-I_{k, k}$ & & & & & 0 \\
\hline Innovative investment & & & & $-I_{c, i}$ & & $-I_{k, i}$ & $+I_{i}$ & $-I_{i, i}$ & & & 0 \\
\hline Wages & $+W B$ & & $-W_{c} N_{c}$ & & $-W_{k} N_{k}$ & & $-W_{i} N_{i}$ & & & & o \\
\hline Profits & & $+F D$ & $-F_{c}$ & $+R E_{c}$ & $-F_{k}$ & $+R E_{k}$ & $-F_{i}$ & $+R E_{i}$ & $-F_{b}$ & & 0 \\
\hline Interests & & & $-r_{l, c,-1} L_{c,-1}$ & & $-r_{l, k,-1} L_{k,-1}$ & & $-r_{l, i,-1} L_{i,-1}$ & & $\sum r_{l,-1} L_{-1}$ & & 0 \\
\hline Traditional capital & & & & $-\Delta K_{c, k}$ & & $-\Delta K_{k, k}$ & & $-\Delta K_{i, k}$ & & & $-\Delta K_{k}$ \\
\hline Innovative capital & & & & $-\Delta K_{c, i}$ & & $-\Delta K_{k, i}$ & & $-\Delta K_{i, i}$ & & & $-\Delta K_{i}$ \\
\hline Deposists & $-\Delta M_{w}$ & $-\Delta M_{C}$ & & $-\Delta M_{C}$ & & $-\Delta M_{k}$ & & & & $+\Delta M$ & 0 \\
\hline Loans & & & & & & & & $+\Delta L_{i}$ & & $-\Delta L$ & 0 \\
\hline Equities & & $-\Sigma \Delta e \cdot p_{e}$ & & $+\Delta e_{c} \cdot p_{c, e}$ & & $+\Delta e_{k} \cdot p_{k, e}$ & & $+\Delta e_{i} \cdot p_{i, e}$ & & & 0 \\
\hline Net Wealth & & $+\Delta V_{c}$ & & & & & & & & & $+\Delta V$ \\
\hline$\Sigma$ & 0 & 0 & 0 & 0 & 0 & 0 & 0 & 0 & 0 & 0 & 0 \\
\hline
\end{tabular}

Table 3: Transaction Flow Matrix 


\section{B. Notation}

\begin{tabular}{|c|c|}
\hline Symbol & Description \\
\hline$c_{x}$ & Real consumption for household sector $x \in\{w, c\}$ \\
\hline$C_{x}$ & Nominal consumption for household sector $x \in\{w, c\}$ \\
\hline$y d_{x}^{e}$ & Expected real disposable income for household sector $x \in\{w, c\}$ \\
\hline$y d_{x}$ & Real disposable income for household sector $x \in\{w, c\}$ \\
\hline$Y D_{x}$ & Nominal disposable income for household sector $x \in\{w, c\}$ \\
\hline$v_{x}$ & Real wealth for household sector $x \in\{w, c\}$ \\
\hline$V_{x}$ & Nominal wealth for household sector $x \in\{w, c\}$ \\
\hline$M_{x}$ & Cash holding for household sector $x \in\{w, c\}$ \\
\hline$Y P_{c}$ & Personal income for capitalist sector \\
\hline$C G$ & Capital gains for capitalist sector \\
\hline$V_{e c}$ & Capitalists wealth held as shares \\
\hline$V_{c}^{e}$ & Expected capitalists wealth \\
\hline$V_{e c}^{e}$ & Expected capitalists wealth held as shares \\
\hline$M_{c}^{d}$ & Desired cash holding for capitalists \\
\hline$Y D_{c}^{e}$ & Expected nominal disposable income for capitalists \\
\hline$c g_{x}^{e}$ & Expected relative capital gains in sector $x \in\{c, k, i\}$ \\
\hline$C G_{x}^{e}$ & Expected capital gains in sector $x \in\{c, k, i\}$ \\
\hline$C G_{x}$ & Capital gains in sector $x \in\{c, k, i\}$ \\
\hline$r_{x}^{e}$ & Expected return rates on equities in sector $x \in\{c, k, i\}$ \\
\hline$F D_{x}^{e}$ & Expected distributed dividends in sector $x \in\{c, k, i\}$ \\
\hline$F D_{x}$ & Dividends distributed in sector $x \in\{c, k, i\}$ \\
\hline$W_{x}$ & Wages in sector $x \in\{c, k, i\}$ \\
\hline$\omega_{x}^{T}$ & Targeted real wages in sector $x \in\{c, k, i\}$ \\
\hline$\overline{p r_{x}}$ & Average productivity in sector $x \in\{c, k, i\}$ \\
\hline$N_{x}$ & Employment in sector $x \in\{c, k, i\}$ \\
\hline$N_{x, y}$ & Employment in sector $x \in\{c, k, i\}$ using capital $y \in\{x, i\}$ \\
\hline$N$ & Total employment \\
\hline$U C_{x}$ & Unit costs in sector $x \in\{c, k, i\}$ \\
\hline$k_{x}$ & Traditional capital stock in sector $x \in\{c, k, i\}$ \\
\hline$i_{x}$ & Innovative capital stock in sector $x \in\{c, k, i\}$ \\
\hline$y_{x}$ & Output in sector $x \in\{c, k, i\}$ \\
\hline$Y_{x}$ & Nominal income in sector $x \in\{c, k, i\}$ \\
\hline$p_{x}$ & Price in sector $x \in\{c, k, i\}$ \\
\hline$\phi_{x}$ & Mark-up in sector $x \in\{c, k, i\}$ \\
\hline$y_{x}^{e}$ & Expected output in sector $x \in\{c, k, i\}$ \\
\hline$\pi_{x}$ & Inflation in sector $x \in\{c, k, i\}$ \\
\hline$g_{y x}$ & Output growth in sector $x \in\{c, k, i\}$ \\
\hline$r r_{l x}$ & Real interes rate in sector $x \in\{c, k, i\}$ \\
\hline$\lambda_{x}$ & Leverage level in sector $x \in\{c, k, i\}$ \\
\hline & Continued on next page \\
\hline
\end{tabular}




\begin{tabular}{|c|l|}
\hline Symbol & Description \\
\hline$\Omega_{x}$ & Capacity utilization in sector $x \in\{c, k, i\}$ \\
$q_{x}$ & Tobin's $q$ in sector $x \in\{c, k, i\}$ \\
$I_{x}$ & Nominal investment in sector $x \in\{c, k, i\}$ \\
$F_{x}$ & Gross profits in sector $x \in\{c, k, i\}$ \\
$\Psi_{x}$ & Share of investment financed through equities emission in sector $x \in\{c, k, i\}$ \\
$e_{x}^{s}$ & Equities emitted in sector $x \in\{c, k, i\}$ \\
$e_{x}$ & Number of equities in sector $x \in\{c, k, i\}$ \\
$p_{e, x}$ & Price of equities in sector $x \in\{c, k, i\}$ \\
$L_{x}$ & Loans requested in sector $x \in\{c, k, i\}$ \\
$c_{x} t_{x}$ & Relative costs of capital good $x \in\{k, i\}$ \\
$i_{y, x}$ & Investment capital good $x \in\{k, i\}$ by sector $y \in\{c, k, i\}$ \\
$r_{l x}$ & Interes rate in sector $x \in\{c, k, i\}$ \\
$r_{x}$ & Average net-of-interest return rate of capital in sector $x \in\{c, k, i\}$ \\
\hline
\end{tabular}

Table 4: Notation 


\begin{tabular}{|c|c|c|c|c|c|}
\hline Symbol & Description & Baseline & $\mathrm{PD}$ & IR & $\overline{\mathrm{BAF}}$ \\
\hline back & $\begin{array}{l}\text { Number of years in the backward look- } \\
\text { ing behavior }\end{array}$ & 4 & 4 & 4 & 4 \\
\hline$\alpha_{c, 1}$ & $\begin{array}{l}\text { Capitalists propensity to consume out } \\
\text { of income }\end{array}$ & 0.6 & 0.6 & 0.6 & 0.6 \\
\hline$\alpha_{c, 2}$ & $\begin{array}{l}\text { Capitalists propensity to consume out } \\
\text { of wealth }\end{array}$ & 0.1 & 0.1 & 0.1 & 0.1 \\
\hline$\alpha_{w, 1}$ & $\begin{array}{l}\text { Wage earners propensity to consume } \\
\text { out of income }\end{array}$ & 0.7 & 0.7 & 0.7 & 0.7 \\
\hline$\alpha_{w, 2}$ & $\begin{array}{l}\text { Wage earners propensity to consume } \\
\text { out of wealth }\end{array}$ & 0.2 & 0.2 & 0.2 & 0.2 \\
\hline$\beta_{c}$ & $\begin{array}{l}\text { Capitalists share of consumption held } \\
\text { as cash }\end{array}$ & 0.3 & 0.3 & 0.3 & 0.3 \\
\hline$\zeta_{1}$ & $\begin{array}{l}\text { Share of relative capital gain in return } \\
\text { rate on equities }\end{array}$ & 0.25 & 0.25 & 0.25 & 0.25 \\
\hline$\zeta_{2}$ & $\begin{array}{l}\text { Share of relative dividends distribution } \\
\text { in return rate }\end{array}$ & 0.375 & 0.375 & 0.375 & 0.375 \\
\hline$\zeta_{3}$ & $\begin{array}{l}\text { Share of relative gross profit rate in re- } \\
\text { turn rate }\end{array}$ & 0.375 & 0.375 & 0.375 & 0.375 \\
\hline$\lambda_{10}$ & $\begin{array}{l}\text { Portfolio choice equation parameter ( } 2 \\
\text { equities) }\end{array}$ & 0.1 & 0.1 & 0.1 & 0.1 \\
\hline$\lambda_{11}$ & $\begin{array}{l}\text { Portfolio choice equation parameter ( } 2 \\
\text { equities) }\end{array}$ & 0.208 & 0.208 & 0.208 & 0.208 \\
\hline$\lambda_{12}$ & $\begin{array}{l}\text { Portfolio choice equation parameter ( } 2 \\
\text { equities) }\end{array}$ & -0.104 & -0.104 & -0.104 & -0.104 \\
\hline
\end{tabular}

Continued on next page. PD: PathDep scenario, IR: InterestRate scenario, BAF:

Bigger and Faster scenario.

37 


\begin{tabular}{|c|c|c|c|c|c|}
\hline Symbol & Description & Baseline & $\mathrm{PD}$ & IR & BAF \\
\hline$\lambda_{13}$ & $\begin{array}{l}\text { Portfolio choice equation parameter ( } 2 \\
\text { equities) }\end{array}$ & -0.104 & -0.104 & -0.104 & -0.104 \\
\hline$\lambda_{21}$ & $\begin{array}{l}\text { Portfolio choice equation parameter ( } 2 \\
\text { equities) }\end{array}$ & -0.104 & -0.104 & -0.104 & -0.104 \\
\hline$\lambda_{22}$ & $\begin{array}{l}\text { Portfolio choice equation parameter ( } 2 \\
\text { equities) }\end{array}$ & 0.312 & 0.312 & 0.312 & 0.312 \\
\hline$\lambda_{23}$ & $\begin{array}{l}\text { Portfolio choice equation parameter ( } 2 \\
\text { equities) }\end{array}$ & -0.208 & -0.208 & -0.208 & -0.208 \\
\hline$\lambda_{31}$ & $\begin{array}{l}\text { Portfolio choice equation parameter ( } 2 \\
\text { equities) }\end{array}$ & -0.104 & -0.104 & -0.104 & -0.104 \\
\hline$\lambda_{32}$ & $\begin{array}{l}\text { Portfolio choice equation parameter ( } 2 \\
\text { equities) }\end{array}$ & -0.208 & -0.208 & -0.208 & -0.208 \\
\hline$\lambda_{33}$ & $\begin{array}{l}\text { Portfolio choice equation parameter ( } 2 \\
\text { equities) }\end{array}$ & 0.312 & 0.312 & 0.312 & 0.312 \\
\hline$\lambda_{10 a}$ & $\begin{array}{l}\text { Portfolio choice equation parameter ( } 3 \\
\text { equities) }\end{array}$ & 0.1 & 0.1 & 0.1 & 0.1 \\
\hline$\lambda_{11 a}$ & $\begin{array}{l}\text { Portfolio choice equation parameter ( } 3 \\
\text { equities) }\end{array}$ & 0.312 & 0.312 & 0.312 & 0.312 \\
\hline$\lambda_{12 a}$ & $\begin{array}{l}\text { Portfolio choice equation parameter ( } 3 \\
\text { equities) }\end{array}$ & -0.104 & -0.104 & -0.104 & -0.104 \\
\hline$\lambda_{13 a}$ & $\begin{array}{l}\text { Portfolio choice equation parameter ( } 3 \\
\text { equities) }\end{array}$ & -0.104 & -0.104 & -0.104 & -0.104 \\
\hline$\lambda_{14 a}$ & $\begin{array}{l}\text { Portfolio choice equation parameter ( } 3 \\
\text { equities) }\end{array}$ & -0.104 & -0.104 & -0.104 & -0.104 \\
\hline$\lambda_{21 a}$ & $\begin{array}{l}\text { Portfolio choice equation parameter ( } 3 \\
\text { equities) }\end{array}$ & -0.104 & -0.104 & -0.104 & -0.104 \\
\hline$\lambda_{22 a}$ & $\begin{array}{l}\text { Portfolio choice equation parameter ( } 3 \\
\text { equities) }\end{array}$ & 0.312 & 0.312 & 0.312 & 0.312 \\
\hline$\lambda_{23 a}$ & $\begin{array}{l}\text { Portfolio choice equation parameter ( } 3 \\
\text { equities) }\end{array}$ & -0.104 & -0.104 & -0.104 & -0.104 \\
\hline$\lambda_{24 a}$ & $\begin{array}{l}\text { Portfolio choice equation parameter ( } 3 \\
\text { equities) }\end{array}$ & -0.104 & -0.104 & -0.104 & -0.104 \\
\hline$\lambda_{31 a}$ & $\begin{array}{l}\text { Portfolio choice equation parameter ( } 3 \\
\text { equities) }\end{array}$ & -0.104 & -0.104 & -0.104 & -0.104 \\
\hline$\lambda_{32 a}$ & $\begin{array}{l}\text { Portfolio choice equation parameter ( } 3 \\
\text { equities) }\end{array}$ & -0.104 & -0.104 & -0.104 & -0.104 \\
\hline$\lambda_{33 a}$ & $\begin{array}{l}\text { Portfolio choice equation parameter ( } 3 \\
\text { equities) }\end{array}$ & 0.312 & 0.312 & 0.312 & 0.312 \\
\hline$\lambda_{34 a}$ & $\begin{array}{l}\text { Portfolio choice equation parameter ( } 3 \\
\text { equities) }\end{array}$ & -0.104 & -0.104 & -0.104 & -0.104 \\
\hline$\lambda_{41 a}$ & $\begin{array}{l}\text { Portfolio choice equation parameter ( } 3 \\
\text { equities) }\end{array}$ & -0.104 & -0.104 & -0.104 & -0.104 \\
\hline
\end{tabular}

Continued on next page. PD: PathDep scenario, IR: InterestRate scenario, BAF: Bigger and Faster scenario. 


\begin{tabular}{|c|c|c|c|c|c|}
\hline Symbol & Description & Baseline & $\mathrm{PD}$ & IR & BAF \\
\hline$\lambda_{42 a}$ & $\begin{array}{l}\text { Portfolio choice equation parameter ( } 3 \\
\text { equities) }\end{array}$ & -0.104 & -0.104 & -0.104 & -0.104 \\
\hline$\lambda_{43 a}$ & $\begin{array}{l}\text { Portfolio choice equation parameter ( } 3 \\
\text { equities) }\end{array}$ & -0.104 & -0.104 & -0.104 & -0.104 \\
\hline$\lambda_{44 a}$ & $\begin{array}{l}\text { Portfolio choice equation parameter ( } 3 \\
\text { equities) }\end{array}$ & 0.312 & 0.312 & 0.312 & 0.312 \\
\hline$\Omega_{0}$ & Real wage target, autonomous term & 0.3 & 0.3 & 0.3 & 0.3 \\
\hline$\Omega_{1}$ & Real wage target, productivity term & 0.1 & 0.1 & 0.1 & 0.1 \\
\hline$\Omega_{2}$ & $\begin{array}{l}\text { Real wage target, aggregate employ- } \\
\text { ment term }\end{array}$ & 0.22 & 0.22 & 0.22 & 0.22 \\
\hline$\Omega_{3}$ & Nominal wage adjustment rate & 0.5 & 0.5 & 0.5 & 0.5 \\
\hline$p r_{k}$ & Productivity of traditional capital & 0.3 & 0.3 & 0.3 & 0.3 \\
\hline$p r_{i}$ & Productivity of innovative capital & 0.33 & 0.33 & 0.33 & 0.33 \\
\hline$l_{k}$ & $\begin{array}{l}\text { Capital-labor ratio of traditional capi- } \\
\text { tal }\end{array}$ & 0.4 & 0.4 & 0.4 & 0.4 \\
\hline$l_{i}$ & Capital-labor ratio of innovative capital & 0.4 & 0.4 & 0.4 & 0.4 \\
\hline$r_{c}^{T}$ & $\begin{array}{l}\text { Return rate on capital in consumption } \\
\text { good sector }\end{array}$ & 0.096 & 0.096 & 0.096 & 0.096 \\
\hline$r_{k}^{T}$ & $\begin{array}{l}\text { Return rate on capital in traditional } \\
\text { capital sector }\end{array}$ & 0.096 & 0.096 & 0.096 & 0.096 \\
\hline$r_{i}^{T}$ & $\begin{array}{l}\text { Return rate on capital in innovative } \\
\text { capital sector }\end{array}$ & 0.096 & 0.096 & 0.096 & 0.096 \\
\hline$\eta_{0}$ & Growth function, autonomous term & -0.03 & -0.03 & -0.03 & -0.03 \\
\hline$\eta_{1}$ & $\begin{array}{l}\text { Growth function, capacity utilization } \\
\text { term }\end{array}$ & 0.05 & 0.05 & 0.05 & 0.05 \\
\hline$\eta_{2}$ & Growth function, debt cost term & 1.25 & 1.25 & 1.25 & 1.25 \\
\hline$\eta_{3}$ & Growth function, Tobin's q term & 0.05 & 0.05 & 0.05 & 0.05 \\
\hline$\eta_{0, i}$ & $\begin{array}{l}\text { Growth function, innovative sector au- } \\
\text { tonomous term }\end{array}$ & 0.06 & 0.06 & 0.06 & 0.06 \\
\hline$\eta_{3, i}$ & $\begin{array}{l}\text { Growth function, innovative Tobin's q } \\
\text { term }\end{array}$ & 0.01 & 0.01 & 0.01 & 0.01 \\
\hline$\psi_{c}$ & $\begin{array}{l}\text { Consumption good sector equities emis- } \\
\text { sion parameter }\end{array}$ & 10 & 10 & 10 & 10 \\
\hline$\psi_{k}$ & $\begin{array}{l}\text { Traditional capital sector equities emis- } \\
\text { sion parameter }\end{array}$ & 10 & 10 & 10 & 10 \\
\hline$\psi_{i}$ & $\begin{array}{l}\text { Innovative capital sector equities emis- } \\
\text { sion parameter }\end{array}$ & 10 & 10 & 10 & 10 \\
\hline$n$ & Life length of capital & 20 & 20 & 20 & 20 \\
\hline$L F$ & Labour force & 1000 & 1000 & 1000 & 1000 \\
\hline entry & Period for entry in the financial market & 40 & 30 & 40 & 40 \\
\hline$\rho$ & $\begin{array}{l}\text { Targeted market share at the entry of } \\
\text { innovators }\end{array}$ & 0.03 & 0.03 & 0.03 & 0.05 \\
\hline
\end{tabular}

Continued on next page. PD: PathDep scenario, IR: InterestRate scenario, BAF:

Bigger and Faster scenario. 


\begin{tabular}{|c|l|l|l|l|l|}
\hline Symbol & Description & Baseline & PD & IR & BAF \\
\hline$\tau$ & Targeted growth rate at the entry of in- & 0.01 & 0.01 & 0.01 & $\mathbf{0 . 0 1 3}$ \\
& novators & & & & \\
$r_{l}$ & Interest rate setting parameter & 0.03 & 0.03 & 0.03 & 0.03 \\
$r_{b}$ & Interest rate setting parameter & 0.073 & 0.073 & $\mathbf{0 . 0 8}$ & 0.073 \\
$\kappa$ & Interest rate setting parameter & 51.28 & 51.28 & $\mathbf{1 0 6 . 3 7 1}$ & 51.28 \\
\hline
\end{tabular}

PD: PathDep scenario, IR: InterestRate scenario, BAF: Bigger and Faster scenario.

Table 5: Parameters 